\title{
Mükemmeliyetçilik ile Depresyon-Anksiyete-Stres İlişkisinde Duygu Düzenleme Güçlüğü ve Belirsizliğe Tahammülsüzlüğün Aracı Rolünün İncelenmesi
}

\author{
Psk. İpek AKTEPE \\ Dicle Üniversitesi, Sosyal Bilimler Enstitüsü, Diyarbakır / Türkiye, \\ aktepeipek@gmail.com, ORCID: 0000-0001-7173-2610 \\ Dr. Öğr. Üyesi Özlem ÇAKMAK-TOLAN* \\ Dicle Üniversitesi, Edebiyat Fakültesi, Psikoloji Bölümü, Diyarbakır / Türkiye, \\ ozlemtolan@gmail.com, ORCID: 0000-0002-8128-6498
}

\section{$\ddot{\mathbf{O} z}$}

Mevcut araştırmanın amacı, mükemmeliyetçiliğin boyutları (kendine yönelik, başkalarına yönelik ve sosyal olarak dayatılan mükemmeliyetçilik) ile depresyon, anksiyete ve stres arasındaki ilişkiyi incelemek ve ardından olası bir ilişkide duygu düzenleme güçlüğü ve belirsizliğe tahammülsüzlügün aracı rolünü belirlemektir. Bu amaç doğrultusunda, araştırma yaşları 18-66 arasında olan 252 katılımcı ile yürütülmüştür. Katılımcılara Kişisel Bilgi Formu, Çok Boyutlu Mükemmeliyetçilik Ölçeği, Belirsizliğe Tahammülsüzlük Ölçeği-Kısa Form, Duygu Düzenleme Güçlüğü Ölçeği-Kısa Form ve Depresyon Anksiyete Stres Ölçeği-Kısa Form uygulanmıştır. Analiz sonuçlarına göre, sosyal olarak dayatılan mükemmeliyetçilik ile depresyon, anksiyete ve stres arasında pozitif yönlü korelasyon bulunmuştur. Başkalarına yönelik mükemmeliyetçilik ile depresyon, anksiyete ve stres ilişkisinde ise, sadece depresyon ile negatif yönlü anlamlı bir ilişki saptanmıştır. Yapılan aracı model anali- 
zinde sadece sosyal olarak dayatılan mükemmeliyetçilik boyutunda anlamlı sonuçlar elde edilmiştir. Sosyal olarak dayatılan mükemmeliyetçilik ve depresyon-anksiyete-stres arasındaki ilişkiye duygu düzenleme güçlüğünün tüm alt boyutları ile aracılık ettiği belirlenmiş̧tir. Sosyal olarak dayatılan mükemmeliyetçilik ve stres ilişkisinde belirsizliğe tahammülsüzlüğün engelleyici kaygı ve ileriye yönelik kaygı boyutları ile aracı role sahip olduğu; sosyal olarak dayatılan mükemmeliyetçilik, depresyon ve anksiyete ilişkisinde ise belirsizliğe tahammülsüzlüğün sadece engelleyici kaygı boyutu ile aracılık ettiği saptanmıştır. Sonuçlar ilgili alanyazın kapsamında tartışılmıştır.

Anahtar Kelimeler: Mükemmeliyetçilik; Depresyon; Anksiyete; Stres; Duygu düzenleme güçlügü; Belirsizliğe tahammülsüzlük.

\title{
Examining the Mediator Role of Emotion Regulation Difficulties and Intolerance to Uncertainty in the Relationship between Perfectionism and Depression-Anxiety-Stress
}

\begin{abstract}
The aim of this study was to examine the relationship between the dimensions of perfection (self-oriented, other oriented, and socially prescribed perfectionism) and depression, anxiety and stress, and then to determine the mediating role of emotion regulation difficulty and intolerance to uncertainty in a possible relationship. For this purpose, the research was carried out with 252 participants between the ages 18-66. The Personal Information Form, Multidimensional Perfectionism Scale (MPS), Intolerance of Uncertainty Scale-Short Form (IUS-12), Difficulties in Emotion Regulation Scale-Brief Form (DERS-16), Depression Anxiety Stress Scale-21 (DASS-21) were applied. Findings showed that a positive correlation was found between socially prescribed perfectionism and depression, anxiety and stress. In addition to this result, other oriented perfectionism only had a significant negative relationship with depression. Significant results were obtained only in the dimension of socially prescribed perfectionism in the mediator model analysis. All sub-dimensions of emotion regulation difficulty mediated relationship between socially prescribed perfectionism and depression, anxiety and stress. In addition, prospective anxiety, inhibitory anxiety subdimensions of the intolerance of uncertainty had a mediating role in the relationship between socially prescribed perfectionism and stress. Also, inhibitory anxiety subdimension of intolerance of uncertainty mediated in the relationship between
\end{abstract}


perfectionism and depression and anxiety. Results were discussed in the context of the literature.

Keywords: Perfectionism; Depression; Anxiety; Stress; Emotion regulation difficulties; Intolerance of uncertainty.

\section{Extended Summary}

\section{Purpose}

Perfectionism is seen as a disposition that completely affects life (Stoeber, 2012). Perfectionism has been studied in three dimensions by Hewitt and Flett (1991a) as self-oriented, other oriented, and socially prescribed perfectionism. In the literature, perfectionism was found to be effective on high level of depression, anxiety and stress (Aldahadha, 2018). Especially, socially prescribed perfectionism has been found to increase negative affect (Tuncer and Voltan-Acar, 2006; Wang and Zhang, 2017). Besides, some mediating variables are thought to play a role in the relationship between perfectionism and depression, anxiety, and stress. Some studies have reported significant relationships between perfectionism, emotion regulation difficulty that the relationship between perfectionism, emotion regulation difficulty (Aldea and Rice, 2006) and intolerance to uncertainty (Carleton et al., 2012) is significant. On the other hand, various studies have found that emotional regulation difficulties and intolerance to uncertainty have mediators role in the relationship between perfectionism and depression, anxiety (McEvoy and Mahoney 2012; Shirazi, 2016).

In this context, the main purpose of the present research was to determine whether there is a relationship between perfectionism and depression-anxiety-stress, and then examining the mediating role of emotion regulation difficulty and intolerance to uncertainty.

\section{Method}

The research was carried out with a total 252 people between 18-66 years of age, living in Diyarbakır, with different socio-economic status. The Personal Information Form, Multidimensional Perfectionism Scale (MPS) (Hewitt and Flett, 1991b; Oral, 1999), Intolerance of Uncertainty Scale-Short Form (IUS-12) (Carleton, Norton and Asmundion, 2007; Sarıçam, Erguvan, Akın and Akça, 2014), Difficulties in Emotion Regulation Scale-Brief Form (DERS-16) (Bjureberg et al., 2016; Yiğit and Guzey-Yiğit, 2019), Depression Anxiety Stress Scale-21 (DASS-21) (Henry and Crawford 2005; Yilmaz, Boz and Arslan 2017) were used for collecting data. 


\section{Result}

The correlation analysis showed no significant relationship between self-perfectionism, depression $(\mathrm{r}=.00, p>.05)$, stress $(\mathrm{r}=.09, p>.05)$ and anxiety $(\mathrm{r}=.10, p>.05)$. Other oriented perfectionism had a significant negative relationship with depression $(\mathrm{r}=-.15, p<.05)$, but it had not significant relationship with stress $(\mathrm{r}=-.06, p>.05)$ and anxiety $(\mathrm{r}=-.06, \mathrm{p}>.05)$. On the other hand, socially prescribed perfectionism had a positive relationship with depression $(\mathrm{r}=.19, p<.001)$, anxiety $(\mathrm{r}=.26, p<.001)$ and stress $(\mathrm{r}=.21, p<.001)$.

In the analysis of mediating variables performed in order to better understand the mechanism of this relationship, it was found that both dimensions of anxiety variable (prospective anxiety, inhibitory anxiety) had a mediator role in the relationship between socially predicted perfectionism and stress. When the mediating role of intolerance to uncertainty in the relationship between socially predicted perfectionism and depression-anxiety was examined, it was determined that only the inhibitory anxiety dimension had a mediating role.

\section{Discussion}

It is emphasized in the literature that other oriented perfectionism is associated with low depression level (Chang and Sanna, 2001) and self-oriented perfectionism does not only cause negative affect (Curran and Hill, 2019). In addition, as socially prescribed perfectionism increases, the level of depression, anxiety and stress increases is compatible with the literature (Jackman, Thorsteinsso and McNeil, 2017; Narimani, 2019).

According to the mediator variable analysis, the high standards set by the environment are critical because of increasing negative affect for people who have difficulties in emotion regulation and less tolerate uncertainties. Possible reasons for this result may be that people with socially prescribed perfectionism are overly reactive to social assessments (Flett, Nepon, Hewitt and Fitzgerald, 2016) and more prone to non-adaptive affects such as shame, guilt, and worthlessness (Klibert, Langhinrichsen-Rohling and Saito, 2005). Besides, the fact that these individuals prefer dysfunctional emotion regulation strategies (Tran and Rimes, 2017), such as impulsive behavior, not accepting affect; also, their need to control obstacles and clarify the possibilities due to fear of negative evaluation may weaken their resistance to uncertainties (Stoeber and Gaudreau, 2017). In this context, it is inevitable for individuals to experience depression, anxiety, and stress. 


\section{Conclusion}

In general, this research has shown that the high standards set by the environment can cause problems that both emotion regulation and coping with uncertainties, and as a result, the individual may experience various affect problems. We believe that the current research will contribute to the literature, since the research on perfectionism is limited especially in our country.

\section{Giriş}

Mükemmeliyetçilik, bireyin kendisinden veya çevresindeki kişilerden, koşulların gerektirdiği performansın üzerinde bir çaba beklentisi içinde olması olarak tanımlanmaktadır (Hollender, 1978). Mükemmeliyetçilik, hayatı bütünüyle etkisi altına alan bir eğilim/mizaç (disposition) olarak da değerlendirilmektedir (Stoeber, 2012). Önceleri mükemmel olmanın sadece kişinin kendisine yönelik ve tek boyutlu olduğu görüşü (Burns, 1980) baskınken, Hewitt ve Flett (1991b) ve Frost, Lahart-Marten ve Rosenblate (1990) tarafindan yapılan araştırmalarla mükemmeliyetçiliğin çok boyutlu bir yapıya sahip olduğu ortaya çıkarılmıştır. Frost ve arkadaşları (1990) mükemmeliyetçiliğin bireysel yönlerini ve ortaya çıkmasında etkili olan faktörleri incelemişlerdir. Bu yapı içerisinde aileden gelen beklenti ve eleştiri, hata yapma endişesi, kişisel standartlar, yaptığından emin olmama, düzene önem verme gibi boyutlar yer almaktadır. Bu araştırmada esas alınan kuram ise Hewitt ve Flett (1991b) tarafindan oluşturulan mükemmeliyetçiliğin üç boyutta ele alındığ 1 kuramdır. Hewitt ve Flett'in (1991b) oluşturduğu boyutlardan ilki, bireyin kendisi için belirlediği yüksek standartlar ve olası sonuçlardan kendisini sorumlu hissettiği kendine yönelik mükemmeliyetçilik boyutudur. İkinci boyut, bireylerin başkaları için belirlediği ve beklentilerinin yüksek olduğu diğerlerine yönelik mükemmeliyetçiliktir. Üçüncü boyut ise, bireylerin çevresindeki kişiler tarafından kendilerine sunulan erişilmesi güç standartların olduğuna dair inancı yansıtan sosyal olarak dayatılan mükemmeliyetçilik olarak açıklanmaktadır (Hewitt ve Flett, 1991a; Hewitt, Flett, Turnbull-Donovan ve Mikail, 1991). Her bir boyutun bireyler üzerindeki etkileri incelendiğinde; başkalarına yönelik mükemmeliyetçiliğe sahip kişilerin günlük hayatlarında iş birlikçi olmadıkları, diğer kişiler ile uyum göstermede yetersiz oldukları ve olaylara karşı daha olumsuz bir bakış açısına sahip oldukları (Stricker, Kritzler ve Buecker, 2019); sosyal olarak dayatılan mükemmeliyetçiliğe sahip kişilerin diğer boyutlara oranla daha çok tükenmişlik yaşadıkları öne sürülmüştür (Childs ve Stoeber, 2010). Mükemmeli- 
yetçiliğin diğer yönü olan kendine yönelik mükemmeliyetçilik ise, bazı araştırmalarda olumlu duygulanım ile ilişkiliyken (Molnar, Reker, Culp, Sadava ve DeCourville, 2006; Noh, 2017) bazı araştırmalarda olumsuz duygulanım (Huggins, Davis, Rooney ve Kane, 2008; Newby ve ark., 2017) ile ilişkili bulunmuştur. Bu bağlamda, mükemmeliyetçiliğin kendi içinde farklı boyutlara ayrıldığ 1 ve bu boyutların bireylerin duygulanımı ve yaşantıları üzerinde hem olumlu hem de olumsuz etkilere sahip olabileceği çarpıcı bir sonuç olarak karşımıza çıkmaktadır.

İlgili alanyazın incelendiğinde, mükemmeliyetçiliğin farklı iki yüzüne vurgu yapan, mükemmeliyetçi mücadele (perfectionistic striving) ve mükemmeliyetçi kaygı (perfectionistic concern) kavramları dikkat çekmektedir (Stoeber ve Otto, 2006). Mükemmeliyetçi mücadele kavramının, kişilerin kendi standartlarını yakalamak için öz-odaklı bir çabayı temsil ettiği ve (Hill, Huelsman ve Araujo, 2010) yaşam doyumu (Gilman, Ashby, Sverko, Florell ve Varjas, 2005), olumlu duygulanım, etkili başa çıkma stratejileri (Dunkley, Zuroff ve Blankstein, 2003) gibi olumlu özellikler ile ilişkili olduğu belirtilmektedir. Mükemmeliyetçi kaygının ise, kişilerin başkaları tarafından olumsuz değerlendirilme, beklentiler ve performans arasındaki farklardan dolayı ortaya çıkan negatif bir duygu olduğu ve depresyon, kaygı gibi psikopatolojiler ile ilişkili olabileceği öne sürülmektedir (Flett ve Hewitt, 2006). Bu bağlamda Rice ve Ashby (2007) tarafindan yapılan bir araştırmada, mükemmeliyetçi mücadele özelliği yüksek, mükemmeliyetçi kaygı özelliği düşük olan kişilerin daha işlevsel oldukları belirlenmiştir. Dibartolo ve Rendón (2012) tarafından yapılan bir başka çalışmada, mükemmeliyetçiliğin boyutları mükemmeliyetçi mücadele ve kaygı açısından incelendiğinde; kendine yönelik mükemmeliyetçilik, mükemmeliyetçi mücadeleyle ilişkili bulunurken, sosyal olarak dayatılan mükemmeliyetçiliğin ise mükemmeliyetçi kaygı ile ilişkili olduğu sonucuna ulaşılmıştır.

Mükemmeliyetçiliğin bir bozukluk olmamakla birlikte, depresyon ve kaygı gibi bozukluklara karşı bir kırılganlık yaratabileceği belirtilmektedir (Egan, Wade ve Shafran, 2011). Araştırmalarda, sosyal olarak dayatılan mükemmeliyetçiliğin depresyon (Wang ve Zhang, 2017) ve kaygı düzeyini (Tuncer ve Voltan-Acar, 2006) açıklayan ve intihar düşüncelerini arttırabilen önemli bir faktör olduğu (Shahnaz, Saffer ve Klonsky, 2018) tespit edilmiştir. Buna ek olarak, sosyal fobinin (Jain ve Sudhir, 2010) ve obsesif kompulsif bozukluğun işlevsel olmayan mükemmeliyetçilik düzeyinin yüksek ol- 
ması ile ilişkili olduğu gösterilmiştir (Moretz ve McKay, 2009). Depresyon ve kaygıyla ilgili bulgulara benzer bir şekilde, sosyal olarak dayatılan mükemmeliyetçiliğin yüksek düzeyde stres ile ilişkili olduğu araştırmalarla ortaya konulmuştur (Ashby ve Gnilka, 2017; Chang ve Rand, 2000). Lynd-Stevenson ve Hearne (1999)'a göre, pasif mükemmeliyetçilik tutumuna sahip kişiler stresli hayat olaylarıyla karşılaştıklarında depresif duygulanımlarında artma görülebilmektedir. Başka bir araştırmada ise, kendine yönelik mükemmeliyetçilik ve hayat stresörlerinin birleşmesi sonucunda depresyon belirtilerinin yükseldiği sonucuna ulaşılmıştır (Flett, Hewitt, Blankstein ve Mosher 1995). İşlevsel olmayan mükemmeliyetçilik, algılanan stres üzerinde etkili olmakta ve negatif değerlendirilme korkusunu arttırmaktadır (Shafique, Gul ve Raseed, 2017). Yapılan bir araştırmada, olumsuz mükemmeliyetçilik boyutunun yükselmesi ile depresyon ve kaygı belirtilerinin arttığı, olumlu mükemmeliyetçilik boyutunun yükselmesi ile depresyon ve kayg1 belirtilerinin azaldığı belirlenmiştir (Aldahadha, 2018). Elde edilen bulgular genel olarak incelendiğinde, bireylerin mükemmeliyetçi özellikleri işlevsel olarak yönetemedikleri durumlarda, günlük hayatlarında karşılaşabilecekleri stresörler ile uygun bir şekilde başa çıamayabilecekleri ve depresyon, kaygı gibi olumsuz duygulanımları daha sık yaşayabilecekleri dikkat çekmektedir. Bu bağlamda bu araştırmanın ilk hipotezi şu şekildedir:

Hipotez 1. Mükemmeliyetçiliğin kendine yönelik, başkalarına yönelik ve sosyal olarak dayatılan mükemmeliyetçilik boyutları ile depresyon, anksiyete ve stres arasında pozitif yönlü bir korelasyon bulunmaktadır.

Mükemmeliyetçilik bazı bireylerde psikolojik iyi oluşa neden olurken, bazı bireylerde ise olumsuz duygulanıma neden olması, mükemmeliyetçilik ve olumsuz duygulanımlar arasında aracı role sahip değişkenler olabileceğini düşündürmektedir. Bu bağlamda, aracılık rolü açısından incelenen kavramlardan biri duygu düzenleme güçlüğüdür. Duygu düzenleme kavramı, duygularımızı ne zaman ne şekilde yaşadığımızı ve onları nasıl yansıttığımızı açıklayan bir kavram olarak ele alınmaktadır (Gross, 2002). Duyguların hem otomatik hem de kontrollü bir süreci yönetirken öncül ve tepki odaklı bir yapıya sahip oldukları belirtilmektedir (Gross ve Muñoz, 1995). Bireyler uyaranlardan gelen ipuçlarını değerlendirir ve ardından bu değerlendirmeler doğrultusunda duygusal bir tepki oluştururlar. Bu tepkinin işlevsel olup olmamasının bireyin kullandığı duygu düzenleme stratejileri ile yakından ilişkili olduğu belirtilmektedir (Gross, 2002). Gratz ve Roemer'e (2004) göre, 
duygu düzenleme stratejileri çok boyutlu bir yapıya sahiptirler ve bireylerin duygularını iyi yönetebilmeleri için öncelikle duygularını tanımaları, anlam verebilmeleri ve onları kabul etmeleri gerekmektedir. Bir diğer strateji, stresli koşullarda bireylerin hedefe yönelik adımlar atabilmeleri ve dürtüsel davranışları kontrol altına alabilmeleridir. Buna ek olarak, duygu stratejilerinin esnek bir yapıda olmaları yaşanılan duruma uygun olarak değişim göstermeleri de önemli bir boyut olarak karşımıza çıkmaktadır. Kişilerin maruz kaldıkları duygusal uyaranlara olması gerekenden daha hassas yaklaşmaları ve duygu içerikli uyaranları karşılamada zorlanmaları ise duygu düzenleme güçlüğü olarak tanımlanmaktadır (Linehan, 1993). Duygu düzenleme güçlüğünün çeşitli psikopatolojiler arasında tanılar arası bir faktör olduğu da ifade edilmektedir (Sloan ve ark., 2017). Duygu düzenlemedeki güçlük, duygusal deneyimlerin yoğunluğunu ve sıklığını etkileyerek duygulanım problemlerine yol açabilmektedir (Gross ve Jazaieri, 2014). D'Avanzato, Joormann, Siemer ve Gotlib (2013) tarafından yapılan araştırmada, major depresif bozukluk ve sosyal fobi tanısına sahip kişilerin duygularını bastırma veya ruminasyon gibi işlevsel olmayan duygu düzenleme stratejilerini daha fazla, durumu yeniden değerlendirme gibi işlevsel stratejileri ise daha az kullandıkları saptanmıştır. Mülteciler ile yapılan bir araştırmada, yüksek düzeydeki depresyon ve kaygının işlevsel olmayan duygu düzenleme stratejileri ile ilişkili olduğu bulunmuştur (Koch, Liedl ve Ehring, 2020). Duygularını yüksek düzeyde bastıran (Gross ve John, 2003), çevresindekiler tarafından olumsuz bir geri dönüt aldıklarında kendilerine veya başkalarına karşı zarar verici davranımlarda bulunabilen (Chester, Mervin ve DeWall, 2015) koşulsuz olarak kabullenilmek isteyen (Scott, 2007), kendilerine karşı aşırı eleştirel olan, duygularını bastırmaya çabalayan ve strese karşı daha duyarlı olan kişilerin daha yüksek düzeyde mükemmeliyetçi özelliklere sahip oldukları ve duygu düzenlemede problemler yaşayabilecekleri, bunun sonucunda da depresyon, anksiyete gibi olumsuz duygulanımlara daha yatkın olabilecekleri ileri sürülmektedir (Rice, Suh ve Davis, 2017). İlgili alanyazında birçok araştırmada mükemmeliyetçilik ve duygu düzenleme arasında anlamlı bir ilişki olduğu belirlenmiştir (Aldea ve Rice, 2006; Smith, Saklofske ve Yan, 2015). Zeifman, Antony ve Kuo (2020) tarafindan yapılan bir araştırmada, mükemmeliyetçi tutum ve intihar düşünceleri arasında ilişki olduğu ve duygu düzenleme güçlüğünün bu ilişkiyi dolaylı olarak etkilediği sonucuna ulaşılmıştır. Duygu düzenleme güçlüğünün benzer bir etkisi dismorfik görüntü kaygısı (Cunningham, Griffiths, Baillie ve Murray, 2018), 
yeme bozuklukları (Donahue, Reilly, Anderdon, Schamer ve Anderson, 2018) ve mükemmeliyetçilik ilişkisinde de saptanmıştır. Shirazi (2016) tarafından yapılan bir araştırmada, mükemmeliyetçilik ve kaygı arasındaki ilişkide duygu düzenlemenin aracı rolü incelenmiştir. Elde edilen sonuçlara göre, sosyal olarak dayatılan mükemmeliyetçilik ve kaygı arasındaki ilişkide duygu düzenlemenin aracı bir rolü olduğu belirlenmiştir. Buna ek olarak, sosyal fobi tanısı alan kişilerin de mükemmeliyetçilik özelliklerine sahip oldukları ve duygu düzenlemede güçlük yaşadıkları saptanmıştır (Rukmini, Sudhir ve Math, 2014). Chang (2012), meslektaşlarına göre daha fazla tükenmişlik yaşayan mükemmeliyetçi tutuma sahip hemşirelerin, ağırlıklı olarak duygu odaklı başa çıkma stratejilerini kullandıklarını belirtmiştir. Başka bir çalışmada, Abdollahi ve Talib (2015) lise öğrencilerinden oluşan bir örneklemde işlevsel olmayan mükemmeliyetçi tutum ile sınav kaygısı arasındaki ilişkide duygusal zekânın önemli bir aracı rolü olduğu sonucuna ulaşmışlardır. Sonuç olarak, yapılan farklı çalışmalarda, mükemmeliyetçiliğin bir kişilik özelliği olarak, bireylerin gündelik hayatta deneyimlerine karş1 verecekleri tepkileri etkileyebileceği ve duyguları yönetebilme konusunda olumsuz sonuçlara yol açabileceği ortaya çıkmaktadır. Bu bilgiler 1şığında araştırmanın ikinci hipotezi şu şekildedir:

Hipotez 2. Mükemmeliyetçiliğin kendine yönelik, başkalarına yönelik ve sosyal olarak dayatılan mükemmeliyetçilik boyutları duygu düzenleme güçlüğü aracılığı ile depresyon, anksiyete ve stresi arttırmaktadır.

Mükemmeliyetçilik ile depresyon, anksiyete ve stres iliş̧isinde aracı rolünün olduğu düşünülen bir diğer değişken belirsizliğe tahammülsüzlüktür. Söz edilen kavram, belirsiz durumlar karşısında kişilerin gösterdiği olumsuz tepkileri kapsamakta ve huzuru bozan, stresli, katlanılması güç durumlar olarak ele alınmaktadır (Birrell, Meares, Wilkinson ve Freeston, 2011). Belirsizliğe tahammülsüzlük, bireylerin belirsizlikler karşısında yanlı değerlendirmeler yapmasını içermektedir. Bireyler belirsiz durumları olumsuz ve sıkıntı verici olarak değerlendirebilir, belirsiz durumlardan kaçınmak isteyebilir ve onlar için olayların kesin olmaması katlanılmaz olabilir (Buhr ve Dugas, 2002). Koerner ve Dugas (2006), belirsizliğe karş1 tahammülsüzlüğü yüksek olan kişilerin net olmayan durumlar karşısında yüksek düzeyde stres yaşadığını, kaçınma gibi uygun olmayan başa çıkma stratejileri kullandıklarını ve '... olursa ne olur?' şeklinde bir düşünme biçimi ile zihinlerinin meşgul olduklarını belirtmişlerdir. Bu bağlamda, belirsizliğe tahammülsüz- 
lüğün kayg1, depresyon ve stres gibi faktörler ile ilişkili olabileceği düşünülmektedir. Kanser tanısı almış kişiler ile yapılan bir araştırmada, belirsizliğe karşı tahammülsüzlük düzeyi arttıkça hem kaygı hem de depresyon semptomlarının arttığı saptanmıştır (Hill ve Hamm, 2019). McEvoy ve Mahoney (2012) tarafından yapılan başka bir çalışmada, belirsizliğe tahammülsüzlük ile sosyal fobi, yaygın anksiyete bozukluğu, depresyon ve obsesif kompülsif bozukluk arasında pozitif yönde ve anlamlı ilişki bulunmuştur. İlgili alanyazında bunu destekleyen farklı araştırma sonuçları da bulunmaktadır (Brown ve ark., 2017; Carleten ve ark., 2012; Einstein, 2014). Belirsizliğe tahammülsüzlük depresyonun bilişsel, duygusal ve somatik semptomları ile ilişkili bulunmaktadır (Saulnier, Allan, Rines ve Schmidt, 2019). Buna ek olarak, belirsizliğe tahammülsüzlüğün kayg1 ve depresyon ile ilişkisi karş1laştırıldığında, kaygının belirsizliğe tahammülsüzlük ile daha güçlü bir ilişkisi olduğu tespit edilmiştir (Jensen, Cohen, Mennin, Fresco ve Heimberg, 2016). İlgili alanyazında yüksek düzeydeki mükemmeliyetçiliğin, artan belirsizliğe tahammülsüzlüğe işaret ettiği de belirtilmektedir (Kavamato ve Frutani, 2018). Buna ek olarak, mükemmeliyetçilik ile obsesif-kompulsif bozukluk (Reuther ve ark., 2013) sinav kaygisı (Wenpeng, Huangyangzi ve Yunxrang, 2016) ve sosyal kaygı (Wang ve Zhang, 2016) arasındaki ilişkide belirsizliğe tahammülsüzlüğün aracı bir rolü olduğu bulunmuştur. Belirsizliğe tahammülsüzlük ve mükemmeliyetçilik ilişkisini inceleyen araştırmalar alanyazında yeterli düzeyde olmamakla birlikte, yapılan araştırmalar genel olarak incelendiğinde, belirsizliğe tahammülsüzlüğün, mükemmeliyetçilik ve depresyon, kayg1 ve stres ilişkisinde arac1 rol alabileceğini düşündürür nitelikte olduğu görülmektedir. Bu doğrultuda oluşturulan hipotez şu şekildedir:

Hipotez 3. Mükemmeliyetçiliğin kendine yönelik, başkalarına yönelik ve sosyal olarak dayatılan mükemmeliyetçilik boyutları belirsizliğe tahammülsüzlük aracılığı ile depresyon, anksiyete ve stresi arttırmaktadır.

Mükemmeliyetçi olmanın olumsuz duygulanım yaşamaya karşı bir k1rllganlık yaratabileceği (Dunkley, Zuroff ve Blankstein, 2003) ve bu ilişkide mükemmeliyetçi yapının altında yatan çeşitli bilişsel faktörler, uyumsuz başa çıkma stratejileri gibi aracı değişkenlerin olabileceği (Hewitt ve ark., 1991) ilgili alanyazında belirtilmiştir. Bu bağlamda, mükemmeliyetçilik ve olumsuz duygulanım arasında anlamlı bir ilişki olabileceği ve bu ilişkiye aracı olabilecek değişkenlerin olduğu yapılan farklı çalışmalarda karşımıza çıkmakla birlikte, özellikle bu mekanizmanın nasıl işlediği konusunda araştır- 
maların sınırlı düzeyde olduğu dikkat çekmektedir. Bu çerçevede, mevcut araştırmanın temel amacı, mükemmeliyetçilik ile depresyon-anksiyete-stres arasında bir ilişki olup olmadığını ve olası bir ilişkide duygu düzenleme ve belirsizliğe tahammülsüzlük değişkenlerinin aracı rolünü belirlemektir.

\section{Yöntem}

\section{Araştırma Modeli}

$\mathrm{Bu}$ araştırmada, ilişkisel tarama modeli esas alınarak değişkenler arasındaki ilişkiler analiz edilmiştir. Bunun yanında, mükemmeliyetçilik ile depresyon, anksiyete ve stres arasındaki ilişkide duygu düzenleme güçlüğü ve belirsizliğe tahammülsüzlüğün aracı rolünü tespit etmek amacıyla aracılık analizi kullanılmıştır.

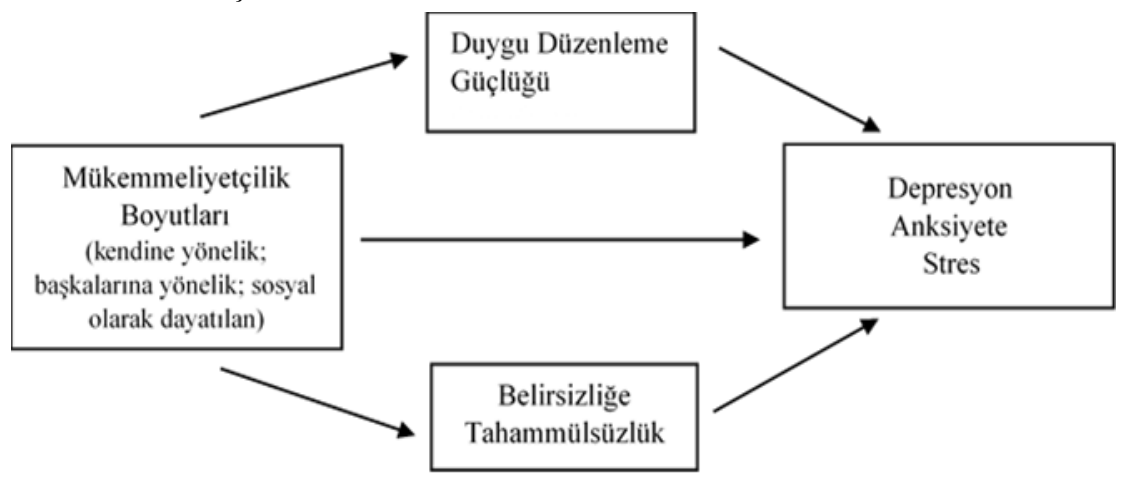

Şekil 1. Araştırma Değişkenleri Arası İlişkilere Yönelik Hipotez Modeli

\section{Çalışma Grubu}

Araştırmaya Diyarbakır ilinde çeşitli kurumlarda çalışan 252 kişi katılmıştır. Katılımcılar uygun örnekleme yöntemi ile seçilmiştir. Bu yöntemde çeşitli sınırlılıklar nedeniyle örneklem araştırmacıların kolay ulaşabildiği birimlerden seçilmektedir (Özen ve Gül, 2007).

Katılımc1ların 81'i (\%32.1) kadın, 171'i (\%67.9) erkektir. Katılımc1ların yaşları 18-66 ( $\mathrm{n}=34.37, \mathrm{ss}=9.76)$ aralığında yer almaktadır. Katılımcıların 148'i (\%58.7) evli, 104'ü (\%41.3) bekârdır. Katılımcıların \%9'u (3.6) ilkokul, 10’u (\%4) ortaokul, 60’1 (\%23.8) lise, 160'1 (\%63.5) üniversite, 13'ü (\%5.2) ise yüksek lisans/doktora mezunlarından oluşmaktadır. Katılımcılar tüm maddi kaynaklarını göz önünde bulundurduklarında kendilerine uygun olan sosyoekonomik düzeyi, 5'i (\%2) çok fakir, 28'i (\%11.1) fakir, 161'i (\%63.9) orta düzey, 42'si (\%16.7) ortanın üstü, 10'u (\%4) varlıklı ve 6's1 (\%2.4) çok varlıklı olarak belirtmişlerdir. 


\section{Verilerin Toplanması}

Veriler Dicle Üniversitesi Sosyal ve Beşerî Bilimler Etik Kurul Başkanlığı'ndan alınan 14.02.2020 tarih 20822 sayılı Etik Kurul Onayını takiben Diyarbakır ilinde yüz yüze toplanmıştır. Katılımcıların yorgunluk etkisi ya da özensiz yanıtlama gibi bazı olası durumların önüne geçmek için veri setleri oluşturulurken ölçeklerin farklı sıralarda yer almasına özen gösterilmiştir. Veri toplama aşamasından önce, tüm katılımcılar araştırmanın içeriği hakkında bilgilendirilmiş ve onam formu verilmiştir. Verilerin gizliliğini korumak amacıyla ölçek formları katılımcılara kapalı zarflarda verilmiş ve ölçeklerin doldurulması işlemi bittikten sonra zarfların kapatılarak araştırmacıya verilmesi istenmiştir.

\section{Veri Toplama Araçları}

\section{Kişisel Bilgi Formu}

Katılımcıların cinsiyet, yaş, medeni hali, eğitim ve maddi durumu gibi demografik bilgilerinin tespit edilmesi amacıyla araştırmacı tarafindan kişisel bilgi formu hazırlanmıştır.

\section{Çok Boyutlu Mükemmeliyetçilik Ölçeği}

Ölçek, bireylerin mükemmeliyetçi tutumlarını belirlemek amacıyla Hewitt ve Flett (1991a) tarafindan geliştirilmiştir. Toplamda 45 maddeden oluşan ölçek, 'kendine yönelik mükemmeliyetçilik', 'başkasına yönelik mükemmeliyetçilik' ve 'sosyal olarak dayatılan mükemmeliyetçilik' olmak üzere 3 alt boyuta ayrılmaktadır. Her bir boyut 15 maddeye sahip olmakla birlikte maddeler 7'li ölçek üzerinden değerlendirilmektedir (1=hiç katılm1yorum, 7=tamamen katılıyorum). Orijinal ölçeğin iç tutarlılık güvenirlik katsayısı kendine yönelik mükemmeliyetçilik alt boyutu için. .86, başkasına yönelik mükemmeliyetçilik alt boyutu için .87 ve sosyal olarak dayatılan mükemmeliyetçilik alt boyutu için .82'dir (Hewitt ve Flett, 1991a). Bu ölçeğin Türkçeye uyarlaması Oral (1999) tarafindan yapılmıştır ve orijinali ile uyumlu olarak ölçeğin, 3 boyutlu bir yapıya sahip olduğu tespit edilmiştir. Uyarlanan ölçeğin iç tutarlılık güvenirlik katsayısı kendine yönelik mükemmeliyetçilik alt boyutunda .91, başkasına yönelik mükemmeliyetçilik alt boyutunda .73 ve sosyal olarak dayatılan mükemmeliyetçilik alt boyutunda .80 olarak belirlenmiştir. Bu çalışmada ise iç tutarlılık tüm maddelerde .83 , kendine yönelik mükemmeliyetçilikte .84 , başkasına yönelik mükemmeliyetçilikte .56 , sosyal olarak dayatılan mükemmeliyetçilikte .58 olarak belirlenmiştir. 


\section{Belirsizliğe Tahammülsüzlük Ölçeği - Kısa Form (BTÖ-12)}

Bireylerin belirsizliğe tahammül düzeylerini değerlendirmek amacı ile Freston, Rheame, Letarte, Dugas ve Ladouceur (1994) tarafından geliştirilmiştir. Ölçekte 27 madde bulunmaktadır. Ölçeğin, 12 maddelik kısa formu ise Freston ve arkadaşlarının (1994) geliştirdiği ölçek esas alınarak Carleton, Norton ve Asmundion (2007) tarafindan oluşturulmuştur. Ölçek, 12 maddeden ve 'ileriye yönelik kaygı', 'engelleyici kaygı' olmak üzere 2 alt boyuttan meydana gelmektedir. 5'li likert (1=bana hiç uygun değil, 5=tamamen uygun) üzerinden puanlanan ölçekte yükselen puanlar, yüksek düzeydeki belirsizliğe tahammülsüzlüğe işaret etmektedir. Orijinal ölçeğin iç tutarlılık güvenirlik katsayısı, tüm maddeler için normal örneklemde .91, klinik örneklemde .92, alt boyutlarda ise .85 olarak bulunmuştur. Ölçeğin Türkçeye uyarlaması Sarıçam, Erguvan, Akın ve Akça (2014) tarafindan yapılmıştır. $\mathrm{Bu}$ çalışmaya göre iç tutarlılık güvenirlik katsayısı, ölçek geneli için .88, ileriye yönelik alt boyutu için .84 ve engelleyici kaygı alt boyutu için ise .77 'dir. Ölçeğin test-tekrar test korelasyon katsayısı .74 olarak saptanmıştır. $\mathrm{Bu}$ çalışmada ise iç tutarlılık değerleri tüm maddeler için .84, ileriye yönelik kaygı için .78 ve engelleyici kaygı için .78 şeklinde hesaplanmıştır.

\section{Duygu Düzenleme Güçlüğü Ölçeği - Kısa Form}

Ölçek duygu düzenleme güçlüğünü saptamak amacıyla Bjureberg ve arkadaşları (2016) tarafından geliştirilmiştir. Toplamda 16 maddeden oluşan ölçek 5'li likert tipindedir ( $1=$ hemen hemen hiç, $5=$ hemen hemen her zaman) ve yükselen puanlar artan duygu düzenleme güçlügünü göstermektedir. Ölçek, 'açıklık', 'amaçlar', 'dürtü', 'stratejiler' ve 'kabul etmeme' olmak üzere 5 alt boyuttan oluşmaktadır. Ölçeğin orijinal çalışmasında iç tutarlılık güvenirlik katsayısı .92 , test-tekrar test güvenirliliği .85'tir. Türkçeye uyarlaması Yiğit ve Guzey-Yiğit (2019) tarafından yapılmıştır. Ölçeğin orijinali ile paralel olarak 5 alt boyuttan oluştuğu ve genel ölçek iç tutarl1lık güvenirlik katsayısı .92 olduğu tespit edilmiştir. Buna ek olarak, alt boyutların iç tutarlılık güvenirlik katsayısı açıklık alt boyutu için .84, amaçlar alt boyutu için .84 , dürtü alt boyutu için .87 , stratejiler alt boyutu için .87 ve kabul etmeme alt boyutu için .78 olarak belirlenmiştir. Ölçeğin Gutman yarıya bölme güvenirlik katsayısı ise .88 olarak bulunmuştur. Bu araştırmada hesaplanan iç tutarlılık katsayıları, tüm maddelerde .92 , açıklık alt boyutunda .85 , amaçlar alt boyutunda .73 , dürtü alt boyutunda .84 , strateji alt boyutunda .84 ve kabul etmeme alt boyutunda .76 olarak belirlenmiştir. 


\section{Depresyon Anksiyete Stres Ölçeği-Kısa Form (DASÖ- 21)}

Bireylerin depresyon, anksiyete ve stres düzeylerini belirlemek amacryla Lovibond ve Lovibond (1995) tarafından geliştirilen ölçekte 42 madde bulunmakta ve 'depresyon', 'anksiyete' ve 'stres' olmak üzere 3 alt boyuttan meydana gelmektedir. 4'lü likert tipindedir ( $0=$ bana uygun değil, $3=$ bana tamamen uygun). Ölçeğin orijinal çalışmasında iç tutarlılık güvenirlik katsayıs1 89 dur. Ölçeğin uzun formunun Türkçeye uyarlaması Akın ve Çetin (2007) tarafından yapılmıştır ve kısa formunun geçerliliği ve güvenirliliği Yılmaz, Boz ve Arslan (2017) tarafından incelenmiştir. Ölçeğin iç tutarlılık güvenirlik katsayısı depresyon alt boyutu için .81, anksiyete alt boyutu için .80 ve stres alt boyutu için .75 olarak saptanmıştır. Bu çalışmadaki iç tutarl1lık katsayıları sırasıyla $.83, .82, .83$ olarak, tüm maddeler için ise .93 olarak belirlenmiştir.

\section{Veri Analizi}

$\mathrm{Bu}$ çalışmada öncelikli olarak, ölçeklerin alt boyutlarından alınan ortalama puanlar, standart sapmalar ve ölçeklerden alınan puanların normal dağılıma uygun olup olmadığının belirlenmesi çarpıklık ve basıklık değerleri aracılığıyla test edilmiştir. Çalışmada kullanılan değişkenler arasındaki ilişkinin belirlenmesi amacıyla korelasyon analizi yapılmıştır. Araştırmadaki arac1 değişken analizleri Preacher ve Hayes tarafından önerilen Bootstrap Yöntemi ile Çoklu Aracılı Model testi ile sınanmıştır (Preacher ve Hayes, 2008). Bu kapsamda, mükemmeliyetçilik ile depresyon, anksiyete ve stres arasındaki ilişkide önce duygu düzenleme güçlüklerinin alt boyutlarının arac1lık rollerinin incelendiği çoklu aracılık modelleri değerlendirilmiştir. Daha sonra ise mükemmeliyetçilik ile depresyon, anksiyete ve stres arasındaki ilişkide Belirsizliğe Tahammülsüzlük Ölçeği'nin alt boyutları olan ileriye yönelik kaygı ve engelleyici kaygı boyutunun aracılık rolleri çoklu aracılık yöntemi ile incelenmiştir. Çoklu aracılık modelinde, aracı yollarının ortalama dolaylı etkileri de hesaplanmış ve her biri için \%99 güven aralıkları ve standart hatalar değerlendirilmiştir. Araştırmadaki modellerin testleri R 3.3.1 programında yer alan "lavaan" versiyon 0.5-22 (Rosseel, 2012) kütüphanesindeki SEM fonksiyonu ile yürütülmüştür.

\section{Bulgular}

\section{Betimsel İstatistik}

Çalışmada ilk olarak katılımcıların ölçeklerden aldıkları puanların ortalamaları, standart sapmaları ve çarpıklık basıklık katsayıları incelenmiştir. 
Tablo 1'de ölçeklere dair betimsel istatistikler görülmektedir.

Tablo 1. Değişkenlere İlişsin Betimsel İstatistikler

\begin{tabular}{|c|c|c|c|c|c|}
\hline Değişken & $\mathbf{N}$ & $\mathbf{X}$ & SS & Çarpıklık & Basıklık \\
\hline Depresyon & 252 & 5.65 & 5.02 & .838 & .031 \\
\hline Anksiyete & 252 & 5.57 & 4.86 & .830 & .044 \\
\hline Stres & 252 & 7.07 & 5.15 & .481 & -548 \\
\hline BTYK & 252 & 25.64 & 5.79 & -.375 & -.213 \\
\hline BTEK & 252 & 16.91 & 4.92 & -228 & -.451 \\
\hline Açık & 252 & 4.77 & 2.14 & .619 & -.214 \\
\hline Amaç & 252 & 8.80 & 3.15 & .120 & -.735 \\
\hline Dürtü & 252 & 7.18 & 3.57 & .730 & -.423 \\
\hline Strateji & 252 & 11.80 & 5.12 & .599 & -.404 \\
\hline Kabul & 252 & 7.32 & 3.48 & .652 & -.186 \\
\hline KYM & 252 & 63.21 & 10.86 & .092 & -.059 \\
\hline BYM & 252 & 36.20 & 8.38 & -.172 & -.125 \\
\hline SODM & 252 & 61.41 & 11.22 & -.221 & .025 \\
\hline
\end{tabular}

\section{Değişkenler Arası İlişkiler}

Araştırmanın değişkenleri arasındaki ilişkileri belirleyebilmek için yapılan Pearson Moment Çarpımlar Korelasyon Analizi sonuçları Tablo 2'de verilmektedir. Elde edilen bulgular mükemmeliyetçilik ve depresyon, stres, anksiyete ilişkisi kapsamında incelendiğinde, kendine yönelik mükemmeliyetçiliğin depresyon $(\mathrm{r}=.00, p>.05)$, stres $(\mathrm{r}=.09, p>.05)$ ve anksiyete $(\mathrm{r}=.10$, $p>.05)$ ile anlamlı bir ilişkiye sahip olmadığı saptanmıştır. Başkalarına yönelik mükemmeliyetçilik ve depresyon arasında negatif yönlü anlamlı bir ilişki vardır $(\mathrm{r}=-.15, p<.05)$ ancak başkalarına yönelik mükemmeliyetçilik ile stres $(\mathrm{r}=-.06, p>.05)$ ve anksiyete $(\mathrm{r}=-.06, p>.05)$ arasında anlamlı bir ilişki bulunmamıştır. Sosyal olarak dayatılan mükemmeliyetçilik ise depresyon $(\mathrm{r}=.19, p<.001)$, anksiyete $(\mathrm{r}=.26, p<.001)$ ve stres $(\mathrm{r}=.21, p<.001)$ ile pozitif yönlü anlamlı bir ilişkiye sahiptir. 
Psk. İpek AKTEPE / Dr. Öğr. Üyesi Özlem ÇAKMAK-TOLAN

Tablo 2. Değiş̧kenler Arasındaki İlişkiyi İnceleyen Pearson Moment Çarpımlar Kc

\begin{tabular}{lccccccccc}
\hline & $\mathbf{1}$ & $\mathbf{2}$ & $\mathbf{3}$ & $\mathbf{4}$ & $\mathbf{5}$ & $\mathbf{6}$ & $\mathbf{7}$ & $\mathbf{8}$ & $\mathbf{9}$ \\
\hline 1.Depresyon & - & $.783^{* *}$ & $.812^{* *}$ & $.177^{* *}$ & $.275^{* *}$ & $.383^{* *}$ & $.437^{* *}$ & $.495^{* *}$ & $.568^{* *}$ \\
2. Anksiyete & - & - & $.817^{* *}$ & $.225^{* *}$ & $.347^{* *}$ & $.425^{* *}$ & $.450^{* *}$ & $.587^{* *}$ & $.536^{* *}$ \\
3. Stres & - & - & - & $.203^{* *}$ & $.322^{* *}$ & $.502^{* *}$ & $.479^{* *}$ & $.561^{* *}$ & $.547^{* *}$ \\
4. BTYK & - & - & - & - & $.530^{* *}$ & $.217^{* *}$ & $.298^{* *}$ & $.315^{* *}$ & $.350^{* *}$ \\
5. BTEK & - & - & - & - & - & $.260^{* *}$ & $.394^{* *}$ & $.428^{* *}$ & $.416^{* *}$ \\
6. AçıK & - & - & - & - & - & - & $.473^{* *}$ & $.432^{* *}$ & $.399^{* *}$ \\
7. Amaç & - & - & - & - & - & - & - & $.644^{* *}$ & $.708^{* *}$ \\
8. Dürtü & - & - & - & - & - & - & - & - & $.776^{* *}$ \\
9. Strateji & - & - & - & - & - & - & - & - & - \\
10. Kabul & - & - & - & - & - & - & - & - & - \\
11. KYM & - & - & - & - & - & - & - & - & - \\
12. BYM & - & - & - & - & - & - & - & - & - \\
13. SODM & - & - & - & - & - & - & - & - & - \\
\hline
\end{tabular}

Not: ${ }^{*} p<.001,{ }^{*} p<.05$, BTYK: Belirsizliğe Tahammülsüzlük Ölçeğinin İleriye Yönelik Kaygı Boyutu, BTEK: Belirsizliğe Tahamm Amaç, Dürtü, Strateji, Kabul: Duygu Düzenleme Güçlükleri Ölçeğinin Boyutlart, KYM: Mükemmeliyetçilik Ölçeğinin Kendine Yör yetçilik Ölçeğinin Başkalarına Yönelik Mükemmeliyetçilik boyutu, SODM: Mükemmeliyetçilik Ölçeğinin Sosyal Olarak Dayatılan $N$ 


\section{Aracılık Analizleri}

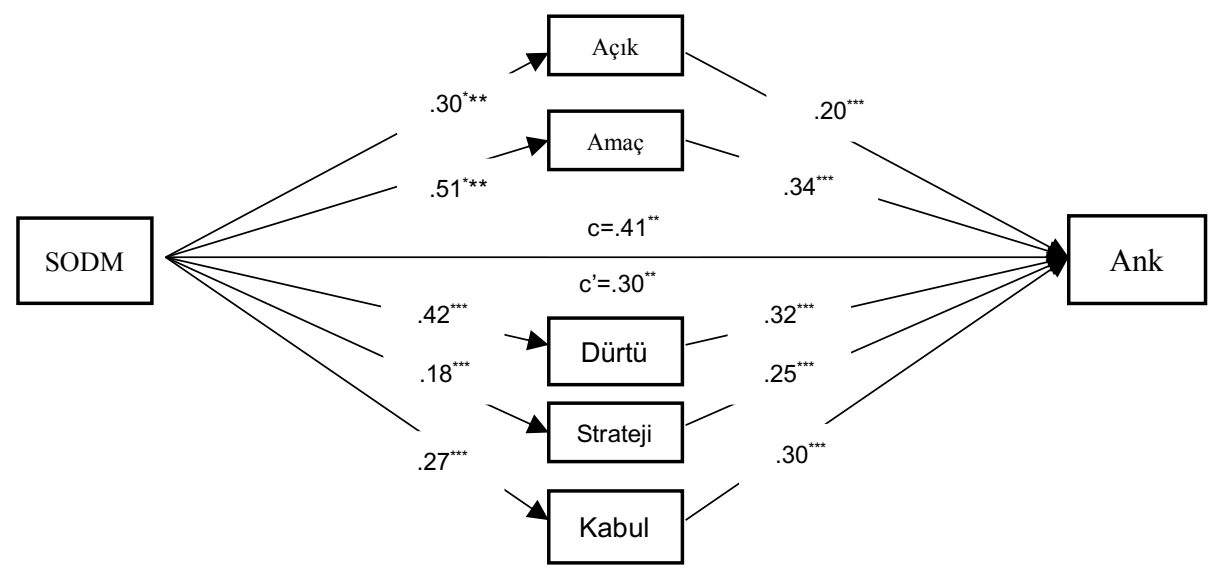

Şekil 2. Sosyal Olarak Dayatılan Mükemmeliyetçilik ile Anksiyete Arasındaki İlişkide Duygu Düzenleme Güçlüğü Alt Boyutlarının Aracılık Rolü Not: ${ }^{*} p<.05,{ }^{* *} p<.01,{ }^{* * *} p<0.001$., SODM: Mükemmeliyetçilik Ölçeğinin Sosyal Olarak Dayatılan Mükemmeliyetçilik boyutu, Açık, Amaç, Dürtü, Strateji, Kabul: Duygu Düzenleme Güçlügü̈ Ölçeğinin boyutlart, Ank: DAS Ölçeğinin Anksiyete alt boyutu.

Şekil 2'de mükemmeliyetçilik ölçeğinin sosyal olarak dayatılan mükemmeliyetçilik boyutu ile anksiyete arasındaki ilişkide duygu düzenleme güçlükleri ölçeğinin alt boyutları olan açıklık, amaç, dürtü, strateji ve kabul etmeme değişkenlerinin aracılık rolleri incelenmiştir. Model incelendiğinde ilk olarak sosyal olarak dayatılan mükemmeliyetçilik ile anksiyete arasındaki doğrudan yolun anlamlı olduğu görülmektedir $(\beta=.41, S H=.016, p<.01)$. Açıkl1k $(\beta=.30, S H=.010, p<.001)$, amaç $(\beta=.51, S H=.018, p<.001)$, dürtü $(\beta=.42, S H=.018, p<.001)$, strateji $(\beta=.18, S H=.026, p<.001)$ ve kabul etmeme $(\beta=.27, S H=.020, p<.001)$ arasındaki yolların anlamlı olduğu görülmektedir. Modeldeki bir diğer bulgu ise açıklık $(\beta=.40, S H=.016, p<.001)$, amaç $(\beta=.55, S H=.012, p<.001)$, dürtü $(\beta=.26, S H=.014, p<.001)$, strateji $(\beta=.14, S H=.009, p<.001)$ ve kabul etmeme $(\beta=.19, S H=.020, p<.001)$ değişkenlerinden anksiyeteye giden yolların anlamlı olduğudur. Son olarak, sosyal olarak dayatılan mükemmeliyetçilik ile anksiyete arasındaki dolaylı yolun da anlamlı olduğu görülmektedir $(\beta=.30, S H=.019, p<.01)$.

Çoklu aracılık modelindeki dolaylı etkilerin anlamlı olup olmadığını test etmek için yapılan bootstrap işlemi sonucunda sosyal olarak dayatılan mükemmeliyetçiliğin duygu düzenlemenin alt boyutları olan açıklık ( $\beta=.036$, $\mathrm{GA}=.008-.070, \mathrm{SH}=.009, p<.01)$, amaç $(\beta=.042, \mathrm{GA}=.014-.038, \mathrm{SH}=.014$, 
$p<.01)$, dürtü $(\beta=.05, \mathrm{GA}=.016-.084, \mathrm{SH}=.015, p<.01)$, strateji $(\beta=.05$, $\mathrm{GA}=.009-.044, \mathrm{SH}=.013, p<.01)$ ve kabul etmeme $(\beta=.05, \mathrm{GA}=.010-.059$, $\mathrm{SH}=.011, p<.01)$, aracilığıyla anksiyete üzerinde anlamlı etkisi olduğu görülmektedir. Ek olarak, çoklu aracılık modelindeki toplam dolaylı yolun da anlamlı olduğu belirlenmiştir $(\beta=.192, \mathrm{GA}=.067-.160, \mathrm{SH}=.025, p<.01)$. Toplam dolaylı etkinin anlamlı olması bütün aracı değişkenlerin aynı anda aracı olduğunda bu etkinin anlamlı olduğunu göstermektedir.

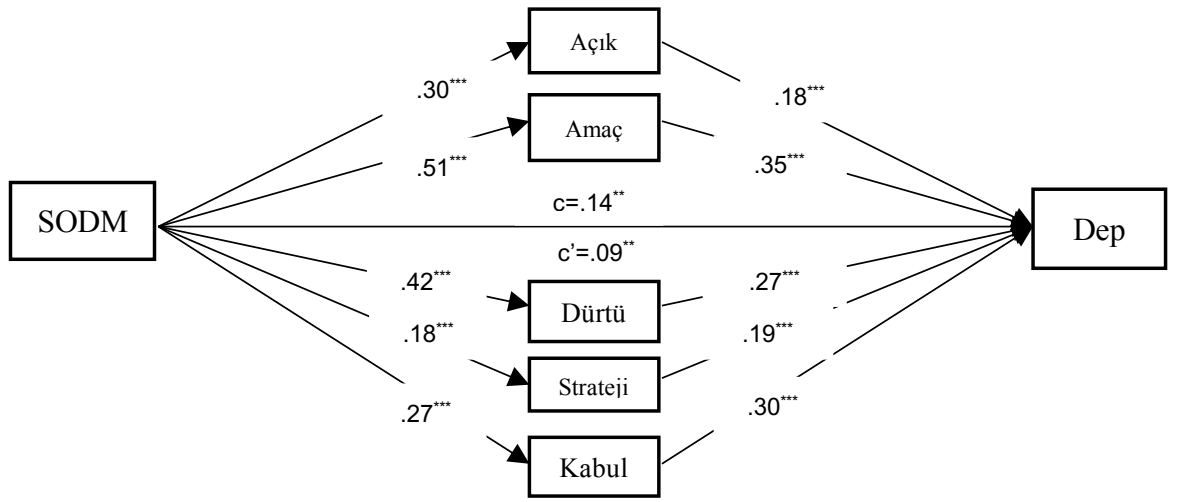

Şekil 3. Sosyal Olarak Dayatılan Mükemmeliyetçilik ile Depresyon Arasındaki İlişkide Duygu Düzenleme Güçlükleri Alt Boyutlarının Aracılık Rolü Not: ${ }^{*} p<.05,{ }^{* *} p<.01,{ }^{* * *} p<0.001$. SODM: Mükemmeliyetçilik Ölçeğinin Sosyal Olarak Dayatılan Mükemmeliyetçilik boyutu, Açık, Amaç, Dürtü, Strateji, Kabul: Duygu Düzenleme Güçlükleri Ölçeğinin boyutlarl, DEP: DAS Ölçeğinin Depresyon alt boyutu

Şekil 3'te sunulan modelde ilk olarak sosyal olarak dayatılan mükemmeliyetçilik ile depresyon arasındaki doğrudan yolun anlamlı olduğu görülmektedir $(\beta=.14, S H=.008, p<.01)$. Analiz sonucu incelendiğinde, sosyal olarak dayatılan mükemmeliyetçilik ile açılık $(\beta=.30, S H=.010$, $p<.001)$, amaç $(\beta=.51, S H=.018, p<.001)$, dürtü $(\beta=.42, S H=.018, p<.001)$, strateji $(\beta=.18, S H=.026, p<.001)$ ve kabul etmeme $(\beta=.27, S H=.020, p<.01)$ arasındaki yolların anlamlı olduğu belirlenmiştir. Modeldeki bir diğer bulgu ise açılklk $(\beta=.18, S H=.017, p<.01)$, amaç $(\beta=.35, S H=.010, p<.001)$, dürtü $(\beta=.27, S H=.013, p<.001)$, strateji $(\beta=.19, S H=.009, p<.01)$ ve kabul etmeme $(\beta=.30, S H=.002, p<.05)$ değişkenlerinden depresyona giden yolların anlamlı olduğudur. Son olarak sosyal olarak dayatılan mükemmeliyetçilik ile depresyon arasındaki dolaylı yolun da anlamlı olduğu saptanmıştır $(\beta=.09$, $S H=.004, p<.01)$.

Analizde yapılan 5000 bootstrap işlemi sonucunda, sosyal olarak dayatılan mükemmeliyetçiliğin duygu düzenlemenin açıklık $(\beta=.036$, 
$\mathrm{GA}=.010-.041, \mathrm{SH}=.009, p<.01)$, amaç $(\beta=.042, \mathrm{GA}=.001-.034, \mathrm{SH}=.014$, $p<.01)$, dürtü $(\beta=.05, \mathrm{GA}=.016-.084, \mathrm{SH}=.015, p<.01)$, strateji $(\beta=.05$, $\mathrm{GA}=.00-.021, \mathrm{SH}=.013, p<.01)$ ve kabul etmeme $(\beta=.05, \mathrm{GA}=.008-.039$, $\mathrm{SH}=.011, p<.001)$ alt boyutları aracıllı̆ıyla depresyon üzerinde anlamlı etkisi olduğunu göstermektedir. Ayrıca modelde toplam dolaylı yolun da anlamlı olduğu görülmektedir $(\beta=.192, \mathrm{GA}=.029-.141, \mathrm{SH}=.027, p<.01)$. Analiz sonucunda hem toplam dolaylı etkinin hem de değişkenlerin dolaylı etkilerinin anlamlı olduğu belirlenmiştir. Elde edilen sonuçlar, duygu düzenleme güçlüğü ölçeğinin bütün alt boyutlarının sosyal olarak dayatılan mükemmeliyetçilik boyutu ile depresyon arasındaki ilişkide aynı anda aracılık etkisi olduğunu göstermektedir.

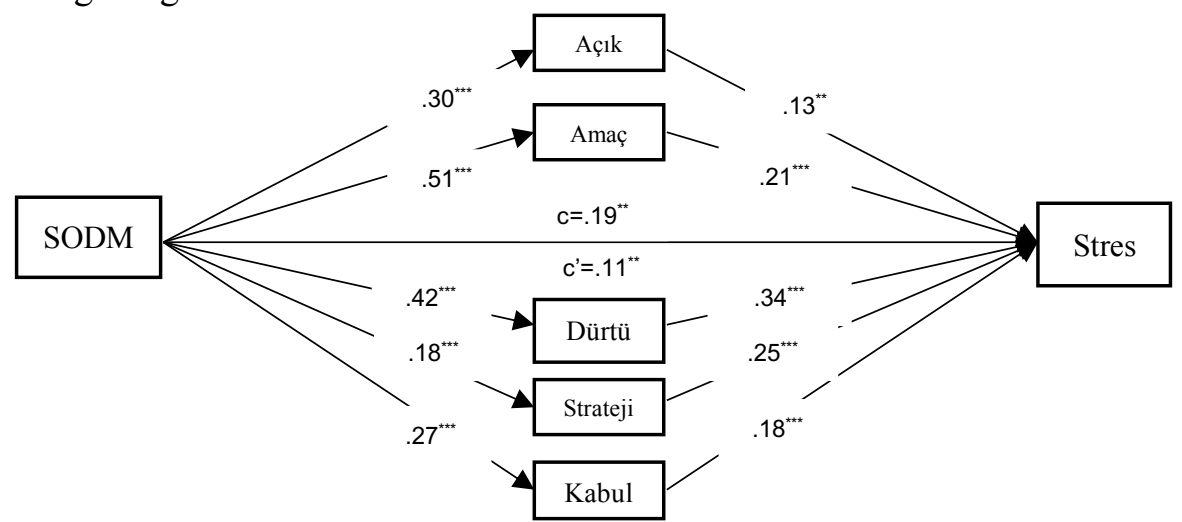

Şekil 4. Sosyal Olarak Dayatılan Mükemmeliyetçilik ile Stres Arasındaki İlişkide Duygu Düzenleme Güçlükleri Alt Boyutlarının Aracılık Rolü Not: ${ }^{*} p<.05,{ }^{* *} p<.01,{ }^{* * *} p<0.001$. SODM: Mükemmeliyetçilik Ölçeğinin Sosyal Olarak Dayatılan Mükemmeliyetçilik boyutu, Açık, Amaç, Dürtü, Strateji, Kabul: Duygu Düzenleme Güçlükleri Ölçeğinin boyutlart, Stres: DAS Ölçeğinin Stres alt boyutu

Şekil 4'te ise sosyal olarak dayatılan mükemmeliyetçilik boyutu ile stres arasındaki ilişkide duygu düzenleme güçlükleri ölçeğinin beş alt boyutunun aracılık etkilerinin incelendiği çoklu aracılık modeli görülmektedir. İlk olarak sosyal olarak dayatılan mükemmeliyetçilik ile stres arasındaki doğrudan yolun anlamlı olduğu görülmektedir $(\beta=.19, \mathrm{SH}=.010, p<.01)$. Modeldeki bir diğer bulgu ise sosyal olarak dayatılan mükemmeliyetçilik ile açıkl1k $(\beta=.30, \mathrm{SH}=.016, p<.01)$, amaç $(\beta=.21, \mathrm{SH}=.011, p<.001)$, dürtü $(\beta=.42$, $\mathrm{SH}=.018, p<.001)$, strateji $(\beta=.18, \mathrm{SH}=.009, p<.001)$ ve kabul etmeme $(\beta=.27, \mathrm{SH}=.014, p<.01)$ arasındaki yolların anlamlı olduğu görülmektedir. Ek olarak, açıklık $(\beta=.13, \mathrm{SH}=.017, p<.01)$, amaç $(\beta=.21, \mathrm{SH}=.010$, $p<.001)$, dürtü $(\beta=.34, \mathrm{SH}=.014, p<.001)$, strateji $(\beta=.25, \mathrm{SH}=.009, p<.001)$ 
ve kabul etmeme $(\beta=.18, \mathrm{SH}=.021, p<.05)$ değişkenlerinden strese giden yolların anlamlı olduğu belirlenmiştir. Son olarak, sosyal olarak dayatılan mükemmeliyetçilik ile stres arasındaki dolaylı yolun da anlamlı olduğu belirlenmiştir $(\beta=.11, \mathrm{SH}=.006, p<.01)$.

Modeldeki dolaylı yolların anlamlı olup olmadığının belirlenmesi amacıyla bootstrap işlemi yapılmıştır. $\mathrm{Bu}$ işlem sonucunda sosyal olarak dayatılan mükemmeliyetçiliğin duygu düzenlemenin açılılı $(\beta=.034$, $\mathrm{GA}=.014-.058, \mathrm{SH}=.002, p<.01)$, amaç $(\beta=.011, \mathrm{GA}=.012-.058, \mathrm{SH}=.010$, $p<.01)$, dürtü $(\beta=.31, \mathrm{GA}=.010-.061, \mathrm{SH}=.012, p<.01)$, strateji $(\beta=.11$, $\mathrm{GA}=.002-.073, \mathrm{SH}=.014, p<.01)$ ve kabul etmeme $(\beta=.06, \mathrm{GA}=.017-.027$, $\mathrm{SH}=.011, p<.01)$ alt boyutları aracılı ̆̆ıla stres üzerinde anlamlı etkisi olduğunu göstermektedir. Modeldeki toplam dolaylı yol incelendiğinde bu yolun da anlamlı olduğu görülmektedir $(\beta=.96, \mathrm{GA}=.029-.141, \mathrm{SH}=.027, p<.01)$. Analiz sonucunda hem toplam dolaylı etkinin hem de değişkenlerin dolaylı etkilerinin anlamlı olduğu saptanmıştır. Elde edilen sonuçlar, duygu düzenleme güçlüğü ölçeğinin bütün alt boyutlarının sosyal olarak dayatılan mükemmeliyetçilik boyutu ile stres arasındaki ilişkide aynı anda aracı olduğunu göstermektedir.

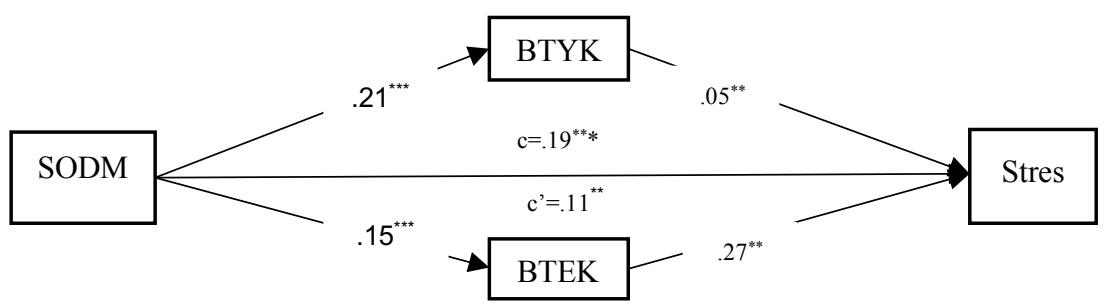

Şekil 5. Sosyal Olarak Dayatılan Mükemmeliyetçilik ile Stres Arasındaki İlişkide Belirsizliğe Tahammülsüzlük Ölçeğinin Alt Boyutlarının Aracılık Rolü

Not: ${ }^{*} p<.05$, **p<.01, ***p<0.001. SODM: Mükemmeliyetçilik Ölçeğinin Sosyal Olarak Dayatılan Mükemmeliyetçilik boyutu, BTYK: Belirsizliğe Tahammülsüzlük Ölçeğinin İleriye Yönelik Kaygı boyutu, BTEK: Belirsizliğe Tahammülsüzlük Ölçeğinin Engelleyici Kaygl boyutu, Stres: DAS Ölçeğinin Stres alt boyutu

Şekil 5'te mükemmeliyetçilik ölçeğinin sosyal olarak dayatılan mükemmeliyetçilik boyutu ile stres arasındaki ilişkide belirsizliğe tahammülsüzlük ölçeğinin alt boyutlarının (ileriye yönelik kaygı ve engelleyici kaygı) aracılık rolü incelenmiştir. Analiz sonucunda sosyal olarak dayatılan mükemmeliyetçilik ile belirsizliğe tahammülsüzlük ölçeğinin ileriye yönelik kaygı boyutu $(\beta=.21, \mathrm{SH}=.011, p<.001)$ ve engelleyici kayg1 boyutu $(\beta=.15$, $\mathrm{SH}=.016, p<.0)$ arasındaki yolların anlamlı olduğu ve benzer şekilde ileriye 
yönelik kayg1 boyutu $(\beta=.15, \mathrm{SH}=.016, p<.01)$ ve engelleyici kayg1 boyutu $(\beta=.21, \mathrm{SH}=.011, p<.001)$ ile stres arasındaki yolların da anlamlı olduğu görülmüştür.

Modeldeki dolaylı etkinin istatistiksel analiz sonuçlara göre, sosyal olarak dayatılan mükemmeliyetçiliğin belirsizliğe tahammülsüzlük ölçeğinin engelleyici kayg1 boyutu $(\beta=.040, \mathrm{GA}=.003-.017, \mathrm{SH}=.014, p<.01)$ ve ileriye yönelik kayg1 boyutunun $(\beta=.011, \mathrm{GA}=-.017-.038, \mathrm{SH}=.013, p<.01)$ arac1lığıyla stres üzerinde anlamlı etkisi olduğu saptanmıştır. Modeldeki toplam dolaylı yolun anlamlı olduğu görülmektedir $(\beta=.96, \mathrm{GA}=.041-.158$, $\mathrm{SH}=.029, p<.01)$.

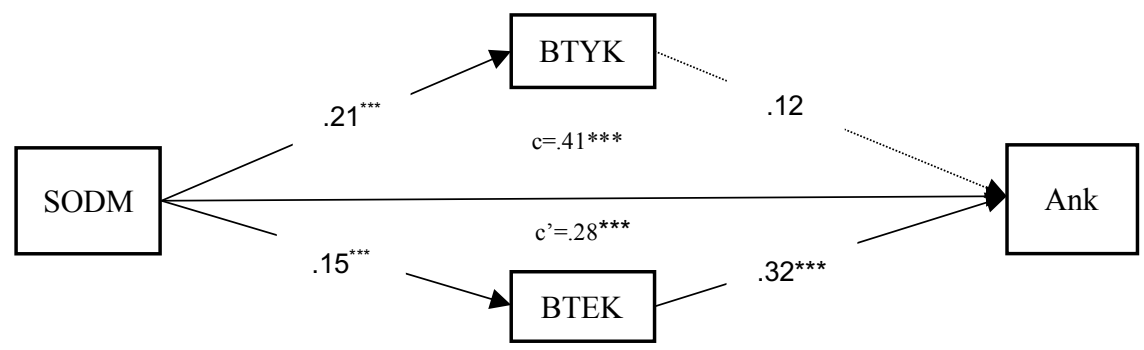

Şekil 6. Sosyal Olarak Dayatılan Mükemmeliyetçilik ile Anksiyete Arasındaki İlişkide Belirsizliğe Tahammülsüzlük Ölçeğinin Alt Boyutlarının Arac1lık Rolü

Not: $*_{p}<.05, * * p<.01, *^{* *} p<0.001$. SODM: Mükemmeliyetçilik Ölçeğinin Sosyal Olarak Dayatılan Mükemmeliyetçilik boyutu, BTYK: Belirsizliğe Tahammülsüzlük Ölçeğinin İleriye Yönelik Kaygı boyutu, BTEK: Belirsizliğe Tahammülsüzlük Ölçeğinin Engelleyici Kaygı boyutu, Ank: DAS Ölçeğinin Anksiyete alt boyutu

Şekil 6'da mükemmeliyetçilik ölçeğinin sosyal olarak dayatılan mükemmeliyetçilik boyutu ile anksiyete arasındaki ilişkide ileriye yönelik kaygı ve engelleyici kaygının aracılık rolü incelenmiştir. Analiz sonucunda sosyal olarak dayatılan mükemmeliyetçilik ile ileriye yönelik kaygı boyutu $(\beta=.21$, $\mathrm{SH}=.011, p<.001)$ ve engelleyici kayg1 boyutu $(\beta=.15, \mathrm{SH}=.016, p<.0)$ arasındaki yolların anlamlı olduğu görülmüştür. Modeldeki diğer yollar engelleyici kaygı boyutu ile anksiyete arasındaki yolun anlamlı olduğu $(\beta=.28$, $\mathrm{SH}=.064, p<.01)$ ancak ileriye yönelik kaygı boyutu ile anksiyete arasındaki yolun istatistiksel açıdan anlamlı olmadığı görülmüştür $(\beta=.12, \mathrm{SH}=.028$, $p>.01)$.

Yapılan bootstrap işlemi sonucunda sosyal olarak dayatılan mükemmeliyetçiliğin, engelleyici kaygı boyutu ( $\beta=.042, \mathrm{GA}=.020-.069, \mathrm{SH}=.012$, $p<.01)$ aracılığıyla anksiyete üzerinde anlamlı etkisi olduğu görülmektedir. 
Modeldeki toplam dolaylı yolun anlamlı olduğu saptanmıştır $(\beta=.12$, $\mathrm{GA}=.068-.167, \mathrm{SH}=.025, p<.01)$.

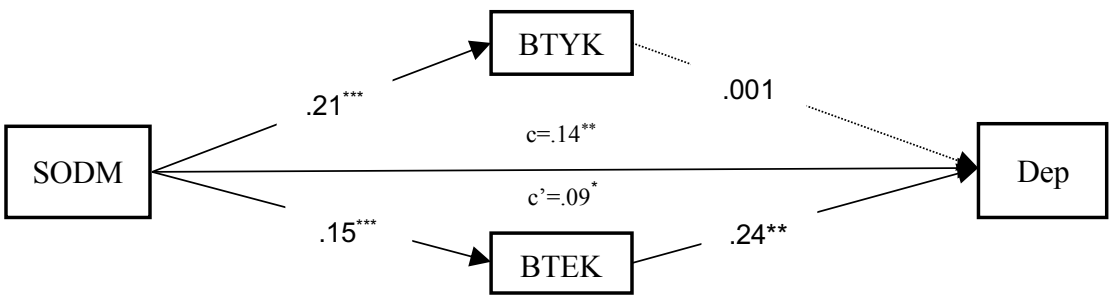

Şekil 7. Sosyal Olarak Dayatılan Mükemmeliyetçilik ile Anksiyete Arasındaki İlişkide Belirsizliğe Tahammülsüzlük Ölçeği Alt Boyutlarının Aracılık Rolü

Not: ${ }^{*} p<.05,{ }^{* *} p<.01,{ }^{* * *} p<0.001$. SODM: Mükemmeliyetçilik Ölçeğinin Sosyal Olarak Dayatılan Mükemmeliyetçilik Boyutu, BTYK: Belirsizliğe Tahammülsüzlük Ölçeğinin İleriye Yönelik Kaygı Boyutu, BTEK: Belirsizliğe Tahammülsüzlük Ölçeğinin Engelleyici Kaygı Boyutu, Dep: DAS Ölçeğinin Depresyon Alt Boyutu

Şekil 7'de mükemmeliyetçilik ölçeğinin sosyal olarak dayatılan mükemmeliyetçilik boyutu ile depresyon değişkenleri arasındaki ilişkide belirsizliğe tahammülsüz ölçeğinin iki alt boyutunun aracılık rolü çoklu aracılık analizi ile belirlenmiştir. Model incelendiğinde sosyal olarak dayatılan mükemmeliyetçilik ile ileriye yönelik kayg1 $(\beta=.21, \mathrm{SH}=.011, p<.001)$ ve engelleyici kayg1 $(\beta=.15, \mathrm{SH}=.016, p<.0)$ arasındaki yolların anlamlı olduğu görülmüştür. Modeldeki diğer yollar incelendiğinde engelleyici kaygı boyutu ile depresyon arasındaki yolun $(\beta=.24, \mathrm{SH}=.070, p<.01)$ anlaml1; ileriye yönelik kaygı boyutu ile depresyon arasındaki yolun ise anlamlı olmadığ 1 saptanmıştır $(\beta=.001, \mathrm{SH}=.06, p>.01)$.

Çoklu aracılık modelindeki dolaylı etkilerin anlamlı olup olmadığı 5000 bootstrap örneklemi üzerinde yanlılık hatasından arındırılmış ve düzeltilmiş sonuçları yansıtan \%99 güven aralığında değerlendirilmiştir. Yapılan bootstrap işlemi sonucunda sosyal olarak dayatılan mükemmeliyetçiliğin, engelleyici kayg1 boyutu $(\beta=.035, \mathrm{GA}=.013-.062, \mathrm{SH}=.013, p<.01)$ aracil1ğıla depresyon üzerinde anlamlı etkisi olduğu görülmektedir. Modeldeki toplam dolaylı yolun anlamlı olduğu sonucuna ulaşılmıştır $(\beta=.09$, $\mathrm{GA}=.036-.138, \mathrm{SH}=.026, p<.01)$. 


\section{Tartışma}

\section{Mükemmeliyetçilik ile Depresyon, Anksiyete ve Stres İlişkisinin Alanyazın Kapsamında İncelenmesi}

Mükemmeliyetçilik boyutları ile depresyon-anksiyete-stres ilişkisi ve bu ilişkinin mekanizmasını anlamak amacıyla yapılan bu araştırmada, öncelikli olarak değişkenler arasında korelasyon analizi yapılmıştır. Elde edilen sonuçlara göre, sosyal olarak dayatılan mükemmeliyetçilik ile depresyon, anksiyete ve stres arasında pozitif yönlü anlamlı bir ilişki olduğu belirlenmiştir. Başkalarına yönelik mükemmeliyetçilik ile depresyon, anksiyete ve stres ilişkisinde ise, sadece depresyon ile negatif yönlü anlamlı bir ilişki saptanmıştır. Kendine yönelik mükemmeliyetçilik ile depresyon, anksiyete ve stres arasında anlamlı bir ilişki bulunmamıştır. Öncelikle, mevcut araştırmanın bulgularıyla uyumlu olarak alanyazında da başkalarına yönelik mükemmeliyetçiliğin düşük depresyon düzeyi ile ilişkili olduğu vurgulanmıştır (Chang ve Sanna, 2001; Chen, Hewitt ve Flett, 2017). Buna ek olarak, başkalarına yönelik mükemmeliyetçiliğin depresyon ile doğrudan bir ilişkisi olmadığı sadece düşük koşulsuz öz-kabul gibi bazı aracı değişkenlerin etkisiyle depresyona neden olabileceği belirtilmiştir (Flett, Besser, Davis ve Hewitt, 2003). Başkalarına yönelik mükemmeliyetçiliğe sahip bireylerin, çevrelerindeki kişilere uygun olmayan standartlar belirlemeleri, beklentileri karşılanmayınca depresyon ve kaygıdan çok öfke düzeylerinin yüksek olmas1 (Curran ve Hill, 2019), narsistik eğilimlere sahip olmaları (Stoeber, Noland, Mawenu, Henderson ve Kent, 2017) gibi faktörlerin bu sonucun altında yatan nedenler arasında olabileceği düşünülmektedir. Başka bir açıdan, başkalarına yönelik mükemmeliyetçiliğe sahip kişilerin kendilerinden çok, yakın ilişki içinde oldukları bireylerin, depresyon düzeylerinin daha yüksek olması da bu görüşü desteklemektedir (Smith ve ark., 2019).

Bir diğer açıdan, en karmaşık boyut olarak değerlendirilen kendine yönelik mükemmeliyetçilik, bireyler üzerinde motivasyonel bir güç oluşturması yönüyle olumlu, bireylerin kendilerine karşı cezalandırıcı yaklaşmaları yönüyle ise olumsuz etkilere sahip olabilmektedir (Curran ve Hill, 2019). Bu çerçevede, kendine yönelik mükemmeliyetçilik iki ayrı perspektiften incelenebilir. Alanyazında bu iki uç kendine yönelik mücadele ve eleştiri şeklinde tanımlanmıştır (Harvey, Moore ve Koestner, 2017). Kendine yönelik mükemmeliyetçiliğin mücadele boyutu dişa dönüklük, sorumluluk, uyumluluk ve yeni deneyimlere açıklık gibi olumlu özellikler ile ilişkiliyken, eleştiri boyutu ise yüksek düzeyde negatif duygulanım ve nevrotiklik ile bağlantılı 
olarak belirlenmiştir (Harvey, Moore ve Koestner, 2017). Bu bağlamda, mevcut araştırma sonuçlarının kendine yönelik mükemmeliyetçiliğin daha olumlu olan tarafına vurgu yaptığg söylenebilir.

Sosyal olarak dayatılan mükemmeliyetçilik, ebeveyn, öğretmen gibi dış kaynaklar tarafından bireyin mükemmel olmasının gerektiğine dair yaratılan algı olarak açıklanmaktadır. Bu çerçevede, bireylerin çevrelerini aşırı talepkâr ve kontrol edilemez olarak değerlendirebilecekleri belirtilmektedir. $\mathrm{Bu}$ boyutun diğer boyutlara oranla bireyler üzerinde olumsuz etkilere daha çok yol açabileceği ileri sürülmektedir (Curran ve Hill, 2019). Bu görüş, mevcut araştırmanın bulgularını desteklemektedir ve alanyazında yer alan araştırmalara ait bulgularda sosyal olarak dayatılan mükemmeliyetçiliğin diğer boyutlara oranla daha fazla depresyon (Jackman, Thorsteinsson ve McNeil, 2017; Smith, Saklofske, Yan ve Sherry, 2018), kaygı (Smith, Vidovic, Sherry, Stewart ve Saklofske, 2018) ve strese (Narimani, 2019) neden olduğu şeklindedir. Malinowski, Veselka ve Atkinson (2017) tarafindan yapılan bir araştırmada, sosyal olarak dayatılan mükemmeliyetçiliğin depresif belirtilerin bir yordayıcısı olduğu, ancak kendine yönelik mükemmeliyetçilik ve başkalarına yönelik mükemmeliyetçiliğin depresif belirtiler ile anlamlı bir ilişkiye sahip olmadığı bulunmuştur. Aynı zamanda, bireyin sahip olduğu yüksek standandartların olumsuz duygulanımı ortaya çıkarmak için yeterli olmadığ (Wu ve ark., 2017) ve kişinin kendi için belirlediği standartların olumlu duygulanımı arttırabileceği de ilgili alanyazında ifade edilmiştir (Gnilka, Ashby ve Noble, 2013). Sosyal olarak dayatılan mükemmeliyetçilik düzeyi yüksek bireylerin, değerlendirilme ve hata yapma kaygısı nedeniyle başarı elde etseler bile, tatmin olmayabilecekleri ve yetersizliğe ilişkin kök bir inançlarının olduğu düşünülmektedir. Yapılan araştırmalarda, sosyal olarak dayatılan mükemmeliyetçiliğin uzun süreli stres tepkisiyle, sosyal değerlendirmelere karşı aşırı tepkisellikle (Flett, Nepon, Hewitt ve Fitzgerald, 2016) ve utanç, suçluluk, değersizlik, erteleme gibi adaptif olmayan davranış ve duygulanımlar ile ilişkili olabileceği belirtilmektedir (Klibert, Langhinrichsen-Rohling ve Saito, 2005). Bir diğer açıdan, bireylerin başkalarının beklentilerini karşılamada zorlanmaları ve motivasyonlarının daha çok dış kaynaklardan sağlanması nedeniyle de hayatlarında yeterli doyuma ulaşamayabilecekleri, düşük düzeyde öz sayg1 ve öz yeterlilik geliştirebilecekleri düşünülmektedir. $\mathrm{Bu}$ durumların sonucunda da depresyon, stres ve kaygı belirtilerinin ortaya çıkabileceği öngörülmektedir. 


\section{Duygu Düzenleme Güçlüğünün Aracı Rolünün Alanyazın Kap- samında İncelenmesi}

Araştırma bulguları depresyon, anksiyete ve stresin sosyal olarak dayatılan mükemmeliyetçilik ile ilişkili olduğunu göstermektedir. Bu ilişkinin mekanizmasını daha iyi anlamak amacıyla yapılan aracı değişken analizlerinde, duygu düzenleme güçlügünün tüm alt boyutları ile sosyal olarak dayatılan mükemmeliyetçilik ile depresyon, anksiyete stres arasındaki ilişkiye aracılık ettiği belirlenmiştir. Elde edilen sonucun alanyazındaki diğer araştırma sonuçları ile uyumlu olduğu görülmüştür (Narl1, 2019; Rukmini, Sudhir ve Math, 2014). Mükemmeliyetçiliğin boyutları çerçevesinden bakıld1ğında, stresli bir durumla karşılaşıldığında, kendine yönelik mükemmeliyetçi tutuma sahip olan kişilerin, yeniden değerlendirme gibi işlevsel duygu düzenleme stratejilerini kullandıkları; sosyal olarak dayatılan mükemmeliyetçilik tutumuna sahip olan kişilerin ise, dürtüsel davranma, duygulanımı kabul etmeme gibi işlevsel olmayan duygu düzenleme stratejilerini kullandıkları tespit edilmiştir (Naghavi, Akbari ve Moradi, 2017; Tran ve Rimes, 2017).

Vois ve Damian (2020) tarafından boylamsal araştırma düzeni ile yapılan bir araştırmada, sosyal olarak dayatılan mükemmeliyetçilik boyutu yüksek olan bireylerin, duygu düzenlemede daha çok işlevsel olmayan yollara başvurdukları belirlenmiştir. Genel olarak, mükemmeliyetçiliğin özellikle de sosyal olarak dayatılan boyutunun yüksek düzeyde olmasının, artan duygu düzenleme problemleri ile ilişkili olduğu alanyazında desteklenmektedir (Castro, Soares, Pereira ve Macedo, 2017). Bu sonucun olası nedenleri duygu düzenleme güçlügünün boyutları kapsamında değerlendirilebilir. Örneğin; duygusal farkındalığa sahip bireyler duygu deneyimlerini tanıyabilir, kabullenebilir ve ne hissettiklerini fark edebilirler, ancak mükemmeliyetçilik arttıkça farkındalık düzeyinin düştüğü öne sürülmektedir (Parling, Mortazavi ve Ghaderi, 2010). Duygu düzenleme hedefleri, duygunun kısa ve uzun vadede neden olacağı sonuçları tartabilmeyi gerektirmektedir. Kısa vadede onaylanmayı sağlayan mükemmeliyetçi davranışlar uzun vadede tükenmişlik duygusuna ve olumsuz duygulanımın artmasina neden olabilmektedir (Madigan, Stoeber ve Passfield, 2016). Mükemmeliyetçi bireylerin yüksek standartları karşılayabilecek ortamları tercih etmeleri, dikkat odaklarında mükemmeliyetçiliğin yer alması (Howell ve ark., 2016), mükemmeliyetçi otomatik düşünceler hata yapma korkusu, ya hep ya hiç tarzı düşünceler (Flett, Hewitt, Blankstein ve Gray, 1998) ve duyguları bastırma gibi işlevsiz mekanizmaların kullanılmasının (Perrone-McGovern, Simon-Dack, Beduna, Wil- 
liams ve Esche, 2015) olumsuz duygulanımın artmasında etkili olabileceği belirtilmektedir (Gross ve John, 2003). Diğer bir açıdan, bireylerin karakteristik özellikleri günlük hayatta karşılaştıkları durumlara karş1 verecekleri tepkiler üzerinde etkili olmakta ve belli tepki örüntülerini benimsemelerine yol açabilmektedir (Gross, 2008). Bu çerçevede, bir kişilik özelliği olarak mükemmeliyetçilik, bireylerin duygu düzenleme becerileri üzerinde belli bir eğilime sahip olmalarına neden olabilir. Özellikle de sosyal olarak dayatılan mükemmeliyetçilik boyutundaki bireyler duyguları yorumlama, fark etme ve uygun başa çıkma stratejileri seçme gibi alanlarda zorluk yaşayabilirler. Mükemmeliyetçilik ile bilişsel duygu düzenleme stratejileri arasındaki ilişkiyi inceleyen bir araştırmada, sosyal olarak dayatılan mükemmeliyetçilik boyutu yüksek bireylerin felaketleştirme, ruminasyon, kendini suçlama gibi işlevsel olmayan stratejileri kullandıkları ve bunun depresyon düzeylerindeki artışa neden olduğu bulunmuştur. Ancak kendine yönelik mükemmeliyetçilik düzeyi yüksek olan bireylerin, kendini suçlama eğiliminde olsalar da bu durumun depresyona neden olmadığı belirtilmektedir (Rudolph, Flett ve Hewitt, 2007). Sosyal olarak dayatılan mükemmeliyetçilik boyutunda bireylerin mükemmel olmadıkları zaman çevresindekiler ile sorun yaşamanın kaçınılmaz olabileceği yönündeki düşüncelerinin, olayların olumsuzluklarına daha fazla odaklanmalarının, deneyimlerini işlevsel bir şekilde yeniden değerlendirmelerinin ve işlevsel olmayan duygu düzenleme mekanizmalarının depresyon anksiyete ve stres duygularının ortaya çıkışı üzerinde etkili olabileceği düşünülmektedir.

\section{Belirsizliğe Tahammülsüzlüğün Aracı Rolünün Alanyazın Kap- samında İncelenmesi}

Mevcut araştırmanın bir diğer bulgusu, belirsizliğe tahammülsüzlügün, sosyal olarak dayatılan mükemmeliyetçilik ile stres ilişkisinde her iki boyutta (ileriye yönelik kaygı, engelleyici kaygı) aracı role sahip olduğu; depresyon ve anksiyete ilişkisinde ise sadece engelleyici kaygı boyutu ile aracı rolünün olduğudur. Bu bulgu ilgili alanyazında yer alan araştırma sonuçları ile uyumludur. Araştırmalar belirsizliğe tahammülsüzlüğün aracı rolünü desteklemekte (Reuther ve ark., 2013; Wang ve Zhang, 2016) ve hem olumsuz duygulanım (Einstein, 2014; Jensen, Cohen, Mennin, Fresco ve Heimberg, 2016; Tobar, Avendaño-Prieto ve Espinosa, 2020) hem de mükemmeliyetçilik ile ilişkili olduğunu göstermektedir (Buhr ve Dugas, 2006). İlgili alanyazında yeterli çalışma olmamakla birlikte, mükemmeliyetçiliğin boyutları ve belirsizliğe tahammülsüzlükle ilgili genel bir çerçevenin çizile- 
bileceği düşünülmektedir. Kawamoto ve Frutani (2018) tarafından yapılan bir araştırmada, belirsizliğe tahammülsüzlüğün işlevsel olmayan mükemmeliyetçilik ve psikolojik uyumsuzluk arasında aracı role sahip olduğu bulunmuştur. Başka bir araştırmada, sosyal olarak dayatılan mükemmeliyetçiliğin depresyon ile ilişkisinde belirsizliğe tahammülsüzlüğün aracı bir role sahip olduğu tespit edilmiştir (Choi ve Song, 2018). Buna ek olarak, belirsizliğe tahammülsüzlüğünün bir boyutu olarak ileriye yönelik kayg1, geleceğin olası getirileri üzerinde hâkim olma isteğiyken, engelleyici kaygı belirsizliklere işlevsel tepki verememe durumunu ifade etmektedir. Söz edilen iki boyutun-mevcut araştırmanın bulgularıyla da uyumlu olarak-farklı psikopatolojilerle ilişkili olduğu vurgulanmaktadır (Fourtounas ve Thomas, 2016). Bulguların altında yatan olası nedenler değerlendirildiğinde, belirsizliğe tahammülsüzlüğün, mükemmeliyetçilik ve her şeyi kontrol altında tutma isteği gibi unsurlar ile bir araya geldiğinde yoğun bir endişeye yol açabileceği öne sürülmektedir (Dugas, Buhr ve Ladouceur, 2004). Buna ek olarak mükemmeliyetçi kişilerin, çevrelerinde olup bitenler ile ilgili kontrol sahibi olmak istedikleri fakat var olan belirsiz durumların kontrol hissini zayıflatabileceği de belirtilmektedir (Ladouceur, Gosselin ve Dugas, 2000). Bu kişilerin öngörülebilirliğe olan isteklerinin mükemmeliyetçiliğin gerektirdiği yüksek beklentilerden kaynaklanabileceği de vurgulanmaktadır (Einstein, 2014). Ayrıca mükemmeliyetçilik ve belirsizliğe tahammülsüzlüğün eş zamanlı olarak işleyebileceği ve mükemmelliğe ulaşmak isteyen bireylerin olumsuz değerlendirilme kaygıları nedeniyle (Stoeber ve Gaudreau, 2017) önlerine çıkabilecek engelleri kontrol altına alma ve olasılıkları kesinleştirme ihtiyacı içinde olabilecekleri belirtilmektedir. Bu çerçevede, mükemmeliyetçi yapıya sahip kişiler hata yapma korkusu ile yürüttükleri görevlerde tüm olasılıkları bilmek isteyebilir, belirsizlikler karşısında daha tepkisel olabilirler ve stres durumunu daha fazla yaşayabilirler. Gümüşoğlu ve Aşçı (2020) tarafindan sporcular ile yapılan bir araştırmada, mükemmeliyetçi özelliklere sahip olan sporcuların, hata yapmaya karşı aşırı hassas olduğu, belirsizliklere tahammül edemediklerini ve iyi performans gösterememekten ötürü endişelendikleri sonucuna ulaşılmıştır. Aynı zamanda, belirsiz olayların yüksek düzeyde tehdit verici olarak algılanmasının mükemmeliyetçi bireyleri savunmasız ve çaresiz hissettirerek olumsuz duygulanıma neden olabileceği düşünülmektedir.

Sosyal olarak dayatılan mükemmeliyetçilik boyutu özelinde düşünüldüğünde ise, bireylerin ebeveyn ya da otorite figürleri tarafindan belirlenen 
standartları karşılamak ve onların onayını kazanmak için aşırı çaba gösterebildikleri görülmektedir. $\mathrm{Bu}$ durumda, yapabileceği her bir hata kişi için başarısızlığa denk tutulabilir ve kontrolü kaybetmemek için sürekli tetikte olabilir. Günlük hayatta her şeyi kontrol altına almanın mümkün olamayacağ1 düşünüldügünde, bilinmeyenin oluşturduğu kaygının, sosyal olarak dayatılan mükemmeliyetçilik boyutunda daha çok ortaya çıkabileceği düşünülmektedir. Başka bir açıdan, Flett, Hewitt, Oliver ve Macdonald (2002) tarafından yapılan bir araştırmada, aşırı korumacı ve sert bir ebeveynlik tutumunun, çocuklarda başarısız olarak görülme ve mükemmel olma kaygısını arttırdığı saptanmıştır. Çocukluk döneminde ebeveynlerin, çocukları yalnızca başarılı olma durumuna bağlı olarak kabul ve ilgi görebilecekleri inancı ile yetiştirmelerinin, bireylerin başarı odaklı olmasına, benliklerini ve öz değerlerini başarılarıyla tanımlamalarına neden olabileceği düşünülmektedir. Bu kapsamda, bireylerde hata yapmaya karşı aşırı hassasiyet artarken belirsizliğe karş1 tahammül kapasitesinin azalabileceği öngörülmektedir.

Mükemmeliyetçilik, yüksek standartları karşılamak için aşırı çaba harcanmasını gerektiren bir özelliktir. Birey duygularını yeterli düzeyde yönetemediğinde, belirsizliklere ve olası hatalara tahammül edemediğinde mükemmeliyetçilik bir mıknatıs gibi olumsuz duygulanımı kendine çekecektir. Giderek artan beklentiler, bireyin kontrol hissini yitirmesine neden olmakla birlikte olayların detaylarına odaklanırken büyük resmi kaçırmasına da neden olabilmektedir. Böylelikle gündelik hayatta, kişilerarası iletişimde veya iş hayatında çeşitli sorunlar ile karşılaşmak kaçınılmaz olabilir. Yapılan bir araştırmada işlevsel olmayan mükemmeliyetçiliğin umutsuzluğu arttırd1ğ1 ve yaşam doyumunu azalttığı bulunmuştur (Gnilka ve ark., 2013). Sosyal olarak dayatılan mükemmeliyetçilik özelinde incelendiğinde ise, kişilerin algıladıkları katı davranış kalıplarını karşılama konusunda kaygı ve stres yaşamaları beklendik bir sonuç olarak karşımıza çıkmaktadır. Ayrıca sosyal olarak dayatılan mükemmeliyetçilik ile ilgili sahip olunan işlevsel olmayan bilişlerin, kişilerin depresyon belirtileri geliştirmelerine neden olabileceği düşünülmektedir. Diğer taraftan, kişinin yüksek standartlara ulaşamadığında yaşaması muhtemel olan kendine yönelik suçlama ve değersizlik duygular1nın depresyon ve stres belirtilerinin ortaya çıkışı üzerinde etkili olabileceği de öngörülmektedir. Bu çerçevede işlevsel olmayan mükemmeliyetçi yaklaşımların onarılmasının, bireylerin psikolojik sağlıkları ve iyilik hali açısından önemli olduğu düşünülmektedir. 
$\mathrm{Bu}$ araştırmanın çeşitli sınırlılıkları bulunmaktadır. İlk olarak, araştırma kesitsel bir dizayna sahiptir fakat boylamsal araştırmalar nedensel ve zamansal ilişkileri daha net bir şekilde ortaya koyabilmektedir. Örneklemin yeterince büyük olmaması ve uygun örnekleme yöntemi ile seçilmesi bulguların genellenebilirliğini kısıtlayan faktörlerdir. Gelecek araştırmalarda bu sinırlılıklara dikkat edilerek mükemmeliyetçilik ile depresyon, anksiyete ve stres arasındaki ilişkinin mekanizması yeniden test edilebilir. Mevcut araştırma klinik olmayan bir örneklem ile yürütülmüştür. İleride yapılacak çalışmalarda klinik bir örneklem üzerinde mükemmeliyetçilik, duygu düzenleme güçlüğü ve belirsizliğe tahammülsüzlük üzerinde etkisi olabilecek fark11 psikolojik değişkenlerin incelenmesinin ilgili alanyazına katkı sunacağ düşünülmektedir. Başka bir açıdan, depresyon ve anksiyete bozukluklarına yönelik yürütülen psikoterapi sürecinde mükemmeliyetçi yapının göz ardı edilmemesinin uygulamacılar için önemli olduğu düşünülmektedir. İleride yapılacak nitel çalışmaların da ilgili değişkenlerin psikolojik boyutlarının anlaşılması açısından önemli olacağı öngörülmektedir.

\section{Sonuç}

Mevcut araştırma sosyal olarak dayatılan mükemmeliyetçilik ile depresyon, anksiyete ve stres arasındaki ilişkide duygu düzenleme güçlüğü ve belirsizliğe tahammülsüzlüğün aracı role sahip olduğunu ortaya çıkarmıştır. Buna ek olarak, başkalarına yönelik mükemmeliyetçilik ve depresyon arasında negatif yönlü bir ilişki varken, kendine yönelik mükemmeliyetçiliğin depresyon, anksiyete ve stres ile anlamlı bir ilişkiye sahip olmadığı bulunmuştur. Mükemmeliyetçilik ve depresyon, anksiyete ve stres arasındaki ilişkinin nasıl işlediği ile ilgili araştırmaların sınırlı olması nedeniyle mevcut araştırmanın alanyazına katkı sunacağı düşünülmektedir.

\section{Kaynakça}

Abdollahi, A. ve Abu Talib, M. (2015). Emotional intelligence moderates perfectionism and test anxiety among Iranian students. School Psychology International, 36(5), 498-512.

Akın, A. ve Çetin, B. (2007). Depresyon, Anksiyete Stres Ölçeği (DASÖ): geçerlik ve güvenirlik çalışması. Kuram ve Uygulamada Eğitim Bilimleri Dergisi, $7(1), 241-268$.

Aldahadha, B. (2018). The psychometric properties of perfectionism scale and its relation to depression and anxiety. Cogent Psychology, 5(1), 1-13.

Aldea, M. A. ve Rice, K. G. (2006). The role of emotional dysregulation in perfectionism and psychological distress. Journal of Counseling Psychology, 53(4), 498-510.

Ashby, J. S. ve Gnilka, P. B. (2017). Multidimensional perfectionism and perceived 
stress: Group differences and test of a coping mediation model. Personality and Individual Differences, 119, 106-111.

Birrell, J., Meares, K., Wilkinson, A. ve Freeston, M. (2011). Toward a definition of intolerance of uncertainty: a review of factor analytical studies of the Intolerance of Uncertainty Scale. Clinical Psychology Review, 31(7), 1198-1208.

Bjureberg, J., Ljótsson, B., Tull, M. T., Hedman, E., Sahlin, H., Lundh, L. G., Bjärehed, J. ve Gratz, K. L. (2016). Development and validation of a brief version of the Difficulties in Emotion Regulation Scale: The DERS-16. Journal of Psychopathology and Behavioral Assessment, 38(2), 284-296.

Brown, M., Robinson, L., Campione, G. C., Wuensch, K., Hildebrandt, T. ve Micali, N. (2017). Intolerance of uncertainty in eating disorders: a systematic review and meta-analysis. European eating disorders review: The Journal of the Eating Disorders Association, 25(5), 329-343.

Buhr, K. ve Dugas, M. J. (2002). The Intolerance of Uncertainty Scale: psychometric properties of the English version. Behaviour Research and Therapy, 40(8), 931-945.

Buhr, K. ve Dugas, M. J. (2006). Investigating the construct validity of intolerance of uncertainty and its unique relationship with worry. Journal of Anxiety Disorders, 20(2), 222-236.

Burn, D. D. (1980). The perfectionist's script for self-defeat. Psychology Today, 14(6), 34-52.

Carleton, R. N., Mulvogue, M. K., Thibodeau, M. A., McCabe, R. E., Antony, M. M. ve Asmundson, G. J. (2012). Increasingly certain about uncertainty: Intolerance of uncertainty across anxiety and depression. Journal of Anxiety Disorders, 26(3), 468-479.

Carleton, R. N., Norton, M. A. ve Asmundson, G. J. (2007). Fearing the unknown: A short version of the Intolerance of Uncertainty Scale. Journal of Anxiety Disorders, 21(1), 105-117.

Castro, J., Soares, M. J., Pereira, A. T. ve Macedo, A. (2017). Perfectionism and negative/positive affect associations: the role of cognitive emotion regulation and perceived distress/coping. Trends in Psychiatry and Psychotherapy, 39(2), 77-87.

Chang, Y. (2012). The relationship between maladaptive perfectionism with burnout: Testing mediating effect of emotion-focused coping. Personality and Individual Differences, 53(5), 635-639.

Chang, E. C. ve Rand, K. L. (2000). Perfectionism as a predictor of subsequent adjustment: Evidence for a specific diathesis-stress mechanism among college students. Journal of Counseling Psychology, 47(1), 129-137.

Chang, E. C. ve Sanna, L. J. (2001). Negative attributional style as a moderator of the link between perfectionism and depressive symptoms: Preliminary evidence for an integrative model. Journal of Counseling Psychology, 48(4), 490-495.

Chen, C., Hewitt, P. L. ve Flett, G. L. (2017). Ethnic variations in other-oriented perfectionism's associations with depression and suicide behaviour. Personality and Individual Differences, 104, 504-509.

Chester, D. S., Merwin, L. M. ve DeWall, C. N. (2015). Maladaptive perfectionism's link to aggression and self-harm: Emotion regulation as a mechanism. 
Aggressive Behavior, 41(5), 443-454.

Childs, J. H. ve Stoeber, J. (2010). Self-oriented, other-oriented, and socially prescribed perfectionism in employees: Relationships with burnout and engagement. Journal of Workplace Behavioral Health, 25(4), 269-281.

Choi, J. G. ve Song, W. (2018). The effect of socially-prescribed perfectionism of college students to depression: Testing the mediation effect of intolerance of uncertainty and unconditional self acceptance. Journal of Convergence for Information Technology, 8(3), 183-191.

Cunningham, M. L., Griffiths, S., Baillie, A. ve Murray, S. B. (2018). Emotion dysregulation moderates the link between perfectionism and dysmorphic appearance concern. Psychology of Men \& Masculinity, 19(1), 59-68.

Curran, T. ve Hill, A. P. (2019). Perfectionism is increasing over time: A meta-analysis of birth cohort differences from 1989 to 2016. Psychological Bulletin, 145(4), 410-429.

D'Avanzato, C., Joormann, J., Siemer, M. ve Gotlib, I. H. (2013). Emotion regulation in depression and anxiety: Examining diagnostic specificity and stability of strategy use. Cognitive Therapy and Research, 37(5), 968-980.

DiBartolo, P. M. ve Rendón, M. J. (2012). A critical examination of the construct of perfectionism and its relationship to mental health in Asian and African Americans using a cross-cultural framework. Clinical Psychology Review, 32(3), 139-152.

Donahue, J. M., Reilly, E. E., Anderson, L. M., Scharmer, C. ve Anderson, D. A. (2018). Evaluating associations between perfectionism, emotion regulation, and eating disorder symptoms in a mixed-gender sample. The Journal of Nervous and Mental Disease, 206(11), 900-904.

Dugas M. J., Buhr K. ve Ladouceur, R. (2004). The role of intolerance of uncertainty in the etiology and maintenance of generalized anxiety disorder. R. G. Heimberg, C. L. Turk, ve D. S. Mennin, (Ed.), Generalized anxiety disorder: advances in research and practice içinde (143-163). New York: Guilford.

Dunkley, D. M., Zuroff, D. C. ve Blankstein, K. R. (2003). Self-critical perfectionism and daily affect: dispositional and situational influences on stress and coping. Journal of Personality and Social Psychology, 84(1), 234-252.

Egan, S. J., Wade, T. D. ve Shafran, R. (2011). Perfectionism as a transdiagnostic process: A clinical review. Clinical Psychology Review, 31(2), 203-212.

Einstein D. A. (2014). Extension of the transdiagnostic model to focus on intolerance of uncertainty: A review of the literature and implications for treatment. Clinical psychology: A publication of the Division of Clinical Psychology of the American Psychological Association, 21(3), 280-300.

Flett, G. L., Besser, A., Davis, R. A. ve Hewitt, P. L. (2003). Dimensions of perfectionism, unconditional self-acceptance, and depression. Journal of Rational-Emotive \& Cognitive-Behavior Therapy, 21(2), 119-138.

Flett, G. L. ve Hewitt, P. L. (2006). Positive versus negative perfectionism in psychopathology: a comment on Slade and Owens's Dual Process Model. Behavior Modification, 30(4), 472-495.

Flett, G. L., Hewitt, P. L., Blankstein, K. R. ve Mosher, S. W. (1995). Perfectionism, life events, and depressive symptoms: A test of a diathesis-stress model. Current Psychology: A Journal for Diverse Perspectives on Diverse Psycho- 
logical Issues, 14(2), 112-137.

Flett, G. L., Hewitt, P. L., Oliver, J. M. ve Macdonald, S. (2002). Perfectionism in children and their parents: A developmental analysis. G. L. Flett ve P.L. Hewitt, (Ed.), Perfectionism, theory, research and treatment içinde (89-132). Washington, DC: American Psychological Association.

Flett, G. L., Nepon, T., Hewitt, P. L. ve Fitzgerald, K. (2016). Perfectionism, components of stress reactivity, and depressive symptoms. Journal of Psychopathology and Behavioral Assessment, 38(4), 645654.

Fourtounas, A. ve Thomas, S. J. (2016). Cognitive factors predicting checking, procrastination and other maladaptive behaviours: prospective versus inhibitory intolerance of uncertainty. Journal of Obsessive-Compulsive and Related Disorders, 9, 30-35.

Freeston, M. H., Rhéaume, J., Letarte, H., Dugas, M. J. ve Ladouceur, R. (1994). Why do people worry? Personality and Individual Differences, 17(6), 791-802.

Frost, R. O., Marten, P., Lahart, C., ve Rosenblate, R. (1990). The dimensions of perfectionism. Cognitive therapy and research, 14(5), 449-468.

Gilman, R., Ashby, J. S., Sverko, D., Florell, D. ve Varjas, K. (2005). The relationship between perfectionism and multidimensional life satisfaction among Croatian and American youth. Personality and Individual Differences, 39(1), 155-166.

Gnilka, P. B., Ashby, J. S. ve Noble, C. M. (2013). Adaptive and maladaptive perfectionism as mediators of adult attachment styles and depression, hopelessness, and life satisfaction. Journal of Counseling \& Development, 91(1), 78-86.

Gratz, K. L. ve Roemer, L. (2004). Multidimensional assessment of emotion regulation and dysregulation: Development, factor structure, and initial validation of the difficulties in emotion regulation scale. Journal of Psychopathology and Behavioral Assessment, 26(1), 41-54.

Gross, J. J. (2002). Emotion regulation: affective, cognitive, and social consequences. Psychophysiology, 39(3), 281-291.

Gross, J. J. (2008). Emotion regulation. M. Lewis, J. M. Haviland-Jones ve L. F. Barrett, (Ed.), Handbook of emotions içinde (497-513). New York: Guilford Press.

Gross, J. J. ve Jazaieri, H. (2014). Emotion, emotion regulation, and psychopathology: an affective science perspective. Clinical Psychological Science, 2(4), 387-401.

Gross, J. J. ve John, O. P. (2003). Individual differences in two emotion regulation processes: implications for affect, relationships, and well-being. Journal of Personality and Social Psychology, 85(2), 348-362.

Gross, J. J. ve Muñoz, R. F. (1995). Emotion regulation and mental health. Clinical Psychology: Science and Practice, 2(2), 151-164.

Gümüşoğlu, Ö. ve Aşçı, H. (2020). Yetişkin sporcularda belirsizliğe tahammülsüzlüğün yordanmasında mükemmeliyetçilik ve zihinsel dayanıklılığın rolü. SPORMETRE Beden Eğitimi ve Spor Bilimleri Dergisi, 18(1), 96-110.

Harvey, B. C., Moore, A. M. ve Koestner, R. (2017). Distinguishing self-oriented perfectionism-striving and self-oriented perfectionism-critical in school-aged 
children: Divergent patterns of perceived parenting, personal affect and school performance. Personality and Individual Differences, 113, 136-141.

Henry, J. D. ve Crawford, J. R. (2005). The short-form version of the Depression Anxiety Stress Scales (DASS-21): construct validity and normative data in a large non-clinical sample. The British Journal of Clinical Psychology, 44(2), 227-239.

Hewitt, P. L. ve Flett, G. L. (1991a). Dimensions of perfectionism in unipolar depression. Journal of Abnormal Psychology, 100(1), 98-101.

Hewitt, P. L. ve Flett, G. L. (1991b). Perfectionism in the self and social contexts: Conceptualization, assessment, and association with psychopathology. Journal of Personality and Social Psychology, 60(3), 456-470.

Hewitt, P. L., Flett, G. L., Turnbull-Donovan, W. ve Mikail, S. F. (1991). The Multidimensional Perfectionism Scale: reliability, validity, and psychometric properties in psychiatric samples. Psychological Assessment: A Journal of Consulting and Clinical Psychology, 3(3), 464-468.

Hill, E. M. ve Hamm, A. (2019). Intolerance of uncertainty, social support, and loneliness in relation to anxietyand depressive symptoms among women diagnosed with ovarian cancer. Psycho-oncology, 28(3), 553-560.

Hill, R. W., Huelsman, T. J. ve Araujo, G. (2010). Perfectionistic concerns suppress associations between perfectionistic strivings and positive life outcomes. Personality and Individual Differences, 48(5), 584-589.

Hollender, M. H. (1978). Perfectionism, a neglected personality trait. The Journal of Clinical Psychiatry, 39(5), 384-384.

Howell, J. A., McEvoy, P. M., Grafton, B., Macleod, C., Kane, R. T., Anderson, R. A. ve Egan, S. J. (2016). Selective attention in perfectionism: Dissociating valence from perfectionism-relevance. Journal of Behavior Therapy and Experimental Psychiatry, 51, 100-108.

Huggins, L., Davis, M. C., Rooney, R. ve Kane, R. (2008). Socially prescribed and self-oriented perfectionism as predictors of depressive diagnosis in preadolescents. Journal of Psychologists and Counsellors in Schools, 18(2), 182-194.

Jackman, L. C., Thorsteinsson, E. B. ve McNeil, D. G. (2017). Perfect imperfections: locus of control, perfectionism and postpartum depression. SAGE Open, $7(2), 1-8$.

Jain, M. ve Sudhir, P. M. (2010). Dimensions of perfectionism and perfectionistic self-presentation in social phobia. Asian Journal of Psychiatry, 3(4), 216-221.

Jensen, D., Cohen, J. N., Mennin, D. S., Fresco, D. M. ve Heimberg, R. G. (2016). Clarifying the unique associations among intolerance of uncertainty, anxiety, and depression. Cognitive Behaviour Therapy, 45(6), 431-444.

Kawamoto, T. ve Furutani, K. (2018). The mediating role of intolerance of uncertainty on the relationships between perfectionism dimensions and psychological adjustment/maladjustment among mothers. Personality and Individual Differences, 122, 62-67.

Klibert, J. J., Langhinrichsen-Rohling, J. ve Saito, M. (2005). Adaptive and maladaptive aspects of self-oriented versus socially prescribed perfectionism. $J_{O}-$ urnal of College Student Development, 46(2), 141-156.

Koch, T., Liedl, A. ve Ehring, T. (2020). Emotion regulation as a transdiagnostic 
factor in Afghan refugees. Psychological Trauma: Theory, Research, Practice, and Policy, 12(3), 235-243.

Koerner, N. ve Dugas, M. J. (2006). A cognitive model of generalized anxiety disorder: the role of intolerance of uncertainty. G. C. L. Davey ve A. Wells, (Ed.), Worry and its psychological disorders: theory, assessment and treatment içinde (201-216). New Jersey: Wiley Publishing.

Ladouceur, R., Gosselin, P. ve Dugas, M. J. (2000). Experimental manipulation of intolerance of uncertainty: a study of a theoretical model of worry. Behaviour Research and Therapy, 38(9), 933-941.

Linehan, M. M. (1993). Skills training manual for treating borderline personality disorder. New York: Guilford Press.

Lovibond, S. H. ve Lovibond, P. F. (1995). Manual for the Depression Anxiety Stress Scale. Sydney: The Psychological Foundation of Australia, Inc.

Lynd-Stevenson, R. M. ve Hearne, C. M. (1999). Perfectionism and depressive affect: The pros and cons of being a perfectionist. Personality and Individual Differences, 26(3), 549-562.

Madigan, D. J., Stoeber, J. ve Passfield, L. (2016). Perfectionism and changes in athlete burnout over three months: Interactive effects of personal standards and evaluative concerns perfectionism. Psychology of Sport and Exercise, 26, 32-39.

Malinowski, A., Veselka, L. ve Atkinson, B. E. (2017). An investigation of vulnerability factors for depression. Personality and Individual Differences, 107, 126-130.

McEvoy, P. M. ve Mahoney, A. E. (2012). To be sure, to be sure: intolerance of uncertainty mediates symptoms of various anxiety disorders and depression. Behavior Therapy, 43(3), 533-545.

Molnar, D. S., Reker, D. L., Culp, N. A., Sadava, S. W. ve DeCourville, N. H. (2006). A mediated model of perfectionism, affect, and physical health. Journal of Research in Personality, 40(5), 482-500.

Moretz, M. W. ve McKay, D. (2009). The role of perfectionism in obsessivecompulsive symptoms: "Not just right" experiences and checking compulsions. Journal of Anxiety Disorders, 23(5), 640-644.

Naghavi, N., Akbari, M. ve Moradi, A. (2017). The structural model of perfectionism based on cognitive, behavioral and emotional transdiagnostic constructs. Research in Psychological Health, 11(2), 19-33.

Narimani, M. (2019). The relationship between perfectionism and stress on life satisfaction in cardiovascular patients in Ardabil. Journal of Ardabil University of Medical Sciences, 19(1), 71-79.

Narlı, M. (2019). Duyu düzenleme güçlüğü ile sınav kaygısı arasındaki ilişkide mükemmeliyetçilik ve obsesif kompulsif belirtilerin aracı rolü. Yayımlanmamış yüksek lisans tezi, Başkent Üniversitesi Sosyal Bilimler Enstitüsü.

Newby, J., Pitura, V. A., Penney, A. M., Klein, R. G., Flett, G. L. ve Hewitt, P. L. (2017). Neuroticism and perfectionism as predictors of social anxiety. Personality and Individual Differences, 106, 263-267.

Noh, G. O. (2017). The effects of perfectionism and academic resilience on the level of students' satisfaction with nursing major. The Journal of Korean Academic Society of Nursing Education, 23(2), 205-213. 
Oral, M. (1999). The relationship between dimensions of perfectionism, stressful life events and depressive symptoms in university students a test of diathesis-stress model of depression. Yayımlanmamış yüksek lisans tezi, Ortadoğu Teknik Üniversitesi Sosyal Bilimler Enstitüsü.

Özen, Y. ve Gül, A. (2007). Sosyal ve eğitim bilimleri araştırmalarında evren-örneklem sorunu. Atatürk Üniversitesi Kazım Karabekir Eğitim Fakültesi Dergisi, 15, 394-422.

Parling, T., Mortazavi, M. ve Ghaderi, A. (2010). Alexithymia and emotional awareness in anorexia nervosa: time for a shift in the measurement of the concept? Eating Behaviors, 11(4), 205-210.

Perrone-McGovern, K. M., Simon-Dack, S. L., Beduna, K. N., Williams, C. C. ve Esche, A. M. (2015). Emotions, cognitions, and well-being: The role of perfectionism, emotional overexcitability, and emotion regulation. Journal for the Education of the Gifted, 38(4), 343-357.

Preacher, K. J. ve Hayes, A. F. (2008). Asymptotic and resampling strategies for assessing and comparing indirect effects in multiple mediator models. Behavior Research Methods, 40(3), 879-891.

Reuther, E. T., Davis, T. E. III, Rudy, B. M., Jenkins, W. S., Whiting, S. E. ve May, A. C. (2013). Intolerance of uncertainty as a mediator of the relationship between perfectionism and obsessive-compulsive symptom severity. Depression and Anxiety, 30(8), 773-777.

Rice, K. G. ve Ashby, J. S. (2007). An efficient method for classifying perfectionists. Journal of Counseling Psychology, 54(1), 72-85.

Rice, K. G., Suh, H., ve Davis, D. E. (2017). Perfectionism and emotion regulation. J. Stoeber, (Ed.). The psychology of perfectionism: theory, research, applica-tions içinde (243-262). London, UK: Routledge.

Rosseel, Y. (2012). Lavaan: an r package for structural equation modeling and more. Version 0.5-12 (BETA). Journal of Statistical Software, 48(2), 1-36.

Rudolph, S. G., Flett, G. L. ve Hewitt, P. L. (2007). Perfectionism and deficits in cognitive emotion regulation. Journal of Rational-Emotive \& Cognitive-Behavior Therapy, 25(4), 343-357.

Rukmini, S., Sudhir, P. M. ve Math, S. B. (2014). Perfectionism, emotion regulation and their relationship to negative affect in patients with social phobia. Indian Journal of Psychological Medicine, 36(3), 239-245.

Sarıçam, H., Erguvan, F. M., Akın, A. ve Akça, M. Ş. (2014). Belirsizliğe Tahammülsüzlük Ölçeği (BTÖ-12) Türkçe formu: geçerlik ve güvenirlik çalışması. Route Educational and Social Science Journal, 1(3), 148-157.

Saulnier, K. G., Allan, N. P., Raines, A. M. ve Schmidt, N. B. (2019). Depression and intolerance of uncertainty: Relations between uncertainty subfactors and depression dimensions. Psychiatry, 82(1), 72-79.

Scott, J. (2007). The effect of perfectionism and unconditional self-acceptance on depression. Journal of Rational-Emotive \& Cognitive-Behavior Therapy, 25(1), 35-64.

Shafique, N., Gul, S. ve Raseed, S. (2017). Perfectionism and perceived stress: The role of fear of negative evaluation. International Journal of Mental Health, 46(4), 312-326.

Shahnaz, A., Saffer, B. Y. ve Klonsky, E. D. (2018). The relationship of perfectio- 
nism to suicide ideation and attempts in a large online sample. Personality and Individual Differences, 130, 117-121.

Shirazi, N. (2016). Perfectionism and generalized anxiety disorder: Investigating the mediating effect of emotion dysregulation. Yayımlanmamış doktora tezi, University of Toronto.

Sloan, E., Hall, K., Moulding, R., Bryce, S., Mildred, H. ve Staiger, P. K. (2017). Emotion regulation as a transdiagnostic treatment construct across anxiety, depression, substance, eating and borderline personality disorders: A systematic review. Clinical Psychology Review, 57, 141-163.

Smith, M. M., Saklofske, D. H. ve Yan, G. (2015). Perfectionism, trait emotional intelligence, and psychological outcomes. Personality and Individual Differences, $85,155-158$.

Smith, M. M., Saklofske, D. H., Yan, G. ve Sherry, S. B. (2017). Does perfectionism predict depression, anxiety, stress, and life satisfaction after controlling for neuroticism? A study of Canadian and Chinese undergraduates. Journal of Individual Differences, 38(2), 63-70.

Smith, M. M., Sherry, S. B., Glowacka, M., Speth, T. A., Stewart, S. H., Saklofske, D. H. ve Etherson, M. E. (2019). Who is the most demanding of them all? A multisource investigation of other-oriented perfectionism, socially prescribed perfectionism, and depressive symptoms. Personality and Individual Differences, 138, 328-332.

Smith, M. M., Vidovic, V., Sherry, S. B., Stewart, S. H. ve Saklofske, D. H. (2018). Are perfectionism dimensions risk factors for anxiety symptoms? A meta-analysis of 11 longitudinal studies. Anxiety, Stress and Coping, 31(1), 4-20.

Stoeber, J. (2012). The $2 \times 2$ model of perfectionism: A critical comment and some suggestions. Personality and Individual Differences, 53(5), 541-545.

Stoeber, J. ve Gaudreau, P. (2017). The advantages of partialling perfectionistic strivings and perfectionistic concerns: Critical issues and recommendations. Personality and Individual Differences, 104, 379-386.

Stoeber, J., Noland, A. B., Mawenu, T. W., Henderson, T. M. ve Kent, D. N. (2017). Perfectionism, social disconnection, and interpersonal hostility: Not all perfectionists don't play nicely with others. Personality and Individual Differences, 119, 112-117.

Stoeber, J. ve Otto, K. (2006). Positive conceptions of perfectionism: Approaches, evidence, challenges. Personality and social psychology review: An Official Journal of the Society for Personality and Social Psychology, Inc, 10(4), 295-319.

Stricker, J., Kritzler, S. ve Buecker, S. (2019). Other-oriented perfectionism in daily life situations: An experience sampling study. Personality and Individual Differences, 151, 1-3.

Doi: 10.1016/j.paid.2019.06.033

Tobar, R. T., Avendaño-Prieto, B. L. ve Espinosa, N. M. V. (2020). Transdiagnostic model of anxiety and depression according to the relationship with affect, intolerance of uncertainly, and anxiety sensitivity. Revista CES Psicología, 13(1), 140-152.

Tran, L. ve Rimes, K. A. (2017). Unhealthy perfectionism, negative beliefs about 
emotions, emotional suppression, and depression in students: A mediational analysis. Personality and Individual Differences, 110, 144-147.

Tuncer, B. ve Voltan-Acar, N. (2006). Kaygı düzeyleri farklı üniversite hazırlık sınıfı öğrencilerinin mükemmeliyetçilik özelliklerinin incelenmesi. Kriz Dergisi, 14(2), 1-15.

Vois, D. ve Damian, L. E. (2020). Perfectionism and emotion regulation in adolescents: A two-wave longitudinal study. Personality and Individual Differences, 156, 1-6.

Doi: 10.1016/j.paid.2019.109756

Y1lmaz, Ö., Boz, H. ve Arslan, A. (2017). Depresyon Anksiyete Stres Ölçeğinin (DASS 21) Türkçe kısa formunun geçerlilik-güvenilirlik çalışması. Finans Ekonomi ve Sosyal Araştırmalar Dergisi (FESA), 2(2), 78-91.

Yiğit, İ. ve Guzey-Yiğit, M. (2019). Psychometric properties of Turkish version of Difficulties in Emotion Regulation Scale-brief form (DERS-16). Current Psychology, 38(6), 1503-1511.

Wang, Y. ve Zhang, R. (2016). Effect of negative perfectionism on social anxiety: mediation effects of intolerance of uncertainty and self-esteem. Psychology: Techniques and Applications, 7, 5-16.

Wang, Y. ve Zhang, B. (2017). The dual model of perfectionism and depression among Chinese University students. South African Journal of Psychiatry, 23(1), 1-7.

Wenpeng, C., Huangyangzi, C. ve Yunxiang, T. (2016). Mediating effect of the intolerance of uncertainty between negative perfectionism and test anxiety. China Journal of Health Psychology, 3, 38-43.

Wu, D., Wang, K., Wei, D., Chen, Q., Du, X., Yang, J. ve Qiu, J. (2017). Perfectionism mediated the relationship between brain structure variation and negative emotion in a nonclinical sample. Cognitive, Affective \& Behavioral Neuroscience, 17(1), 211-223.

Zeifman, R. J., Antony, M. M. ve Kuo, J. R. (2020). When being imperfect just won't do: Exploring the relationship between perfectionism, emotion dysregulation, and suicidal ideation. Personality and Individual Differences, 152, $1-5$.

Doi: 10.1016/j.paid.2019.109612 